
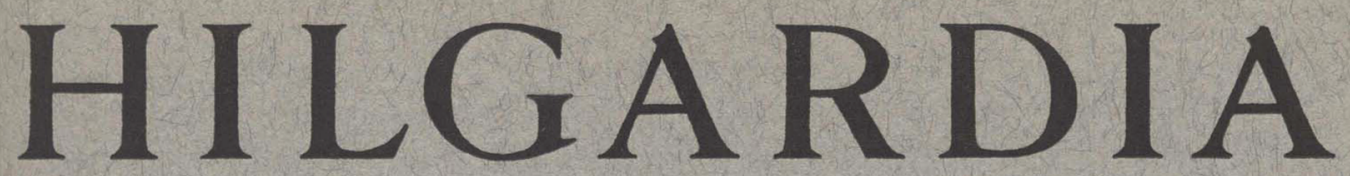

A Journal of Agricultural Science Publisbed by the California Agricultural Experiment Station

\title{
LABORATORY EXPERIMENTS ON THE \\ CONTROL OF THREE SPECIES OF FRUIT FLIES (TEPHRITIDAE)
} WALTER EBELING

\section{FIELD EXPERIMENTS ON THE CONTROL OF THE MELON FLY, DACUS CUCURBITAE} WALTER EBELING, T. NISHIDA, AND H. A. BESS 


\section{Laboratory experiments ...}

.... on control of the melon fly and the Mediterranean and oriental fruit flies included tests on a total of 26 insecticides. Equipment designed on the venturi principle facilitated application of aerosols, dusts, and sprays, for both space and residue treatments.

Factors that might influence the results of treatments were found to be species, adult age, and sex of the flies and, in residue treatments, period of contact with residues, anesthetization, and number of flies per cage. The last two and the species seem to operate through effects on fly activity.

Of the insecticides tested as wettable powders in residue treatment, the thirteen most effective were parathion, dieldrin, EPN, heptachlor, lindane, aldrin, dilan, chlordane, toxaphene, methoxychlor, DFDT, DDT, and DDD. In other formulations and in space treatment the order was somewhat different.

Dosages of DDT and parathion residues that gave less than 100 per cent kill had little effect on the subsequent mortality and egg laying of melon flies that survived the treatment.

Of 17 wettable-powder residues tested, dieldrin retained effectiveness longest - about 2 weeks - on exposure to sun and rain. When sheltered from sun and rain, the residues from dieldrin, EPN, and parathion sprays resulted in 100 per cent kills of melon flies and oriental fruit flies more than 4 months after treatment.

\section{Field experiments on control of the melon fly in Hawaii ...}

... showed that, owing to the habits of the insect, treating the crop itself is futile in preventing crop damage, even with insecticides that were highly effective in laboratory tests.

In contrast, treating a one- or two-row border of corn planted around the crop field with high concentrations of insecticide once a week (twice a week if it rained) was effective in protecting cucumbers, watermelons, and tomatoes. Treating near-by wild vegetation increased the effectiveness. The insecticides successfully used were DDT, methoxychlor, aldrin, dieldrin, EPN, and parathion wettable powders. The field tests furnished no basis for a comparison of their relative effectiveness.

A number of insecticides were tested by laboratory cage tests for effectiveness of residues after weathering. Among those tested, parathion and chlordane lost effectiveness most rapidly, especially if there were rains; dilan (not used in field tests), dieldrin, EPN, and DDT retained high effectiveness for 10 or 11 days after spraying when there were no heavy rains. The tests indicated wide differences among insecticides in the toxicant concentration required for good control. 


\title{
FIELD EXPERIMENTS ON THE CONTROL OF THE MELON FLY, DACUS CUCURBITAE ${ }^{1}$
}

\author{
WALteR EBELING, T. NISHIDA, AND H. A. BESS ${ }^{2}$
}

INSECTICIDES found promising in the laboratory experiments reported in the companion paper (Ebeling, 1953a) were tested for their effectiveness against the melon fly, Dacus cucurbitae (Coquillett) under field conditions in Hawaii. The field experiments, in which the Hawaii Agricultural Experiment Station coöperated, were conducted on the island of Oahu from June, 1950, to June, 1951. As indicated in the companion paper, the objectives were to find effective insecticides and suitable dosages for eradicating the melon fly if it should be introduced into California and for controlling it and protecting susceptible crops if it should become permanently established there.

\section{PREVIOUS INVESTIGATIONS AND PRACTICES}

None of the control methods now used commercially in Hawaii for the melon fly-some of them very intensive and costly-are effective enough to prevent a high percentage of infested, unmarketable fruits.

Protective Coverings. Growers have for many years attempted to protect cucurbit fruits from the melon fly with various types of protective coverings (Severin, Severin, and Hartung, 1914 ; Back and Pemberton, 1917 ; McPhail, 1943). Newspapers, held down at the edges with earth, are the covering now most widely used. The method, time-consuming and expensive as it is, fails to prevent great loss of fruit. Often the flowers are "stung" by the flies before the paper can be put in place after pollination, or gaps develop in the covers, or the covers blow away.

Crop-Field Spraying and Dusting. Holdaway, et al. (1947) reduced the percentage of infested tomatoes to about 32 per cent by eight treatments of the crop field with DDT dusts ; this was in a field where prior to treatment the flies were so numerous that complete crop failure seemed likely.

In recent years many growers have been treating their crops with sprays or dusts of DDT, or, within the last year or two, with parathion. These treatments are often made several times a week, and sometimes as often as once or even twice a day, with the maximum dosage tolerated by the crops, and are often supplemented by covering the fruits with newspapers. Despite this intensive program of treatment, much damage to cucurbit and tomato crops results if the flies are abundant.

Traps and Bait Sprays. Previous investigators have been unsuccessful in reducing crop damage adequately by bait traps, even when large numbers of flies were captured (McPhail, 1943); or by bait sprays of an arsenical

${ }^{1}$ Received for publication December 6, 1951.

${ }^{2}$ Walter Ebeling is Associate Professor of Entomology and Entomologist in the California Agricultural Experiment Station; T. Nishida is Junior Entomologist and H. A. Bess is Professor of Entomology and Entomologist, both in the Hawaii Agricultural Experiment Station. 
and a lure, applied to the crop, even though large numbers of flies were killed (Severin, Severin, and Hartung, 1914; Back and Pemberton, 1917).

Treatment of Borders. The most promising control methods thus far developed have been treatments of borders, either of wild vegetation or of trap or barrier plantings around the crop field. Severin, Severin, and Hartung (1914) observed that adult flies may be found feeding on various wild plants for as much as 100 yards away from the crop field that forms their breeding grounds. These investigators obtained effective reduction in the fly population by spraying a narrow strip of the bordering vegetation as well as the crop field with an arsenical bait spray, but reported that the soluble poisons used in these sprays burned the foliage and hence could not be advocated.

Nishida and Bess (1950) reported that male and immature female melon flies were seldom found in tomato and melon fields but were congregated on wild plants in the vicinity. Gravid females comprised about 90 per cent of the adult-melon-fly population within tomato fields; they apparently entered the fields during the day and left in the evening. Crop fields were practically free of flies during the night and early-morning hours. This suggested the possibility of controlling the flies by treating the areas bordering the crop fields at these periods. A mist spray of 10 to 12 weight/volume per cent emulsifiable DDT, applied to the surrounding vegetation in four early-morning treatments about 1 week apart, reduced the average infestation of tomato fruits to 3 per cent, as compared with 65 per cent in near-by check fields dusted with a 3 per cent DDT dust about twice a week. The fact that treatment did not involve the application of poisonous insecticides to the crop to be protected further enhanced its value.

\section{MATERIALS AND METHODS}

Insecticides Tested. The insecticides included in one or more field tests were parathion, dieldrin, EPN, heptachlor, lindane, aldrin, chlordane, and DDT as suspensions of wettable powders ; parathion, dieldrin, lindane, chlordane, and methoxychlor as dusts; and rotenone and methoxychlor as kerosene emulsions. Laboratory cage tests of foliage treated in the field included tests on dilan and toxaphene. The composition of all these materials is given in the companion paper.

All of the materials listed had given an excellent kill of the flies in the laboratory as space sprays (Ebeling, 1953a) ; but in selecting them particular weight was given to laboratory results with residue treatments. Longlasting effectiveness is especially important in eradication work and, in view of the melon-fly habits observed by previous investigators, seemed likely to be important in crop protection also. Accordingly, the present experiments were particularly directed toward finding a formulation that would give long-lasting effectiveness under field conditions. No emulsifiables were tested because the laboratory experiments had shown that the wettable powders had greater residual effectiveness per unit of insecticide deposited and, in addition, emulsifiables were not available for all the insecticides tested. In the light of more recent evidence, it appears that it might have been desirable to test whatever emulsifiables were available for, on the average, they are usually more persistent on foliage than the wettable powders, particularly 
if the weathering is primarily from rain. They also have a tendency, because of greater persistence, to accumulate from repeated sprayings (Ebeling, 1953b).

Crop and Border Treatments. Treatment of the crop itself was tried in two early experiments, one with cucumbers and one with tomatoes.

It was soon found, however, that when applied to the crops once a week, even the materials that had been the most effective in laboratory tests would not protect the fruits from the melon fly unless applied in concentrations too high for crop tolerance or public-health standards. Furthermore, cornborder treatment was better adapted for a comparison of the effectiveness of the insecticides under field conditions, particularly in connection with laboratory cage tests of treated foliage. Hence subsequent experiments were confined to treatments of corn borders planted around the crop field and, with one field, surrounding wild vegetation.

Equipment. Except as otherwise noted, conventional sprays were applied with a 150-gallon power sprayer delivering 5.5 gallons per minute through one nozzle, with a pressure of 250 pounds. A Monarch spray nozzle was used at the end of a $31 / 2$-foot rod. This nozzle may be set at an angle so that, by twisting the rod, one can spray either up from beneath the foliage or down on the upper leaf surfaces.

Mist sprays were applied with a Lawrence mist blower, which delivered a fine mist at the rate of about 48 gallons per hour. A large quantity of air is forced out of a fan or blower duct at high velocity, atomizing and propelling the liquid spray mixture and forming a mist.

Dusts were applied at night with a rotary knapsack duster equipped with a spout that could be adjusted to throw a cloud of dust upwards from under the leaves.

Evaluating Results. Observations of marked flies released in a field (see p. 572) indicated that there was not only considerable intrafield movement, but also a marked tendency for the flies to move toward one end. This indicated that it would be extremely difficult to carry out randomized small plot experiments with this insect. Therefore no check plots were used in these studies, except in the first crop-field treatment. Instead, fly counts, trap catches, or vine or fruit damage, or a combination of these, were used as a basis of evaluating treatments. The consistent heavy or total loss of crops in Hawaii without treatment and the limited effectiveness of current commercial practices also provide some basis for evaluating results.

In two fields the effectiveness of the insecticides as a space spray on the flies actually contacted was tested by placing flies in sleeve cages ${ }^{3}$ on the plants.

In one field, flies were placed in sleeve cages over foliage or fruit 1 and 7 days after treatment to test the effectiveness of the residue on flies actually contacted. Such attempts to evaluate the residual effects, however, were not sufficiently reliable because of uncontrollable factors, such as destruction of flies by ants.

\footnotetext{
3 The sleeve cages were loaned for the experiment by Dr. C. H. Spiegelburg, Plant Pathologist for the Pineapple Research Institute. They were made of plastic fly screen pulled over galvanized wire frames to make a cylindrical cage 10 inches in diameter and 14 inches long. The insects were introduced through a slit in the closed end, which could then be tied together.
} 
To better evaluate residual effectiveness, laboratory cage tests were made in conjunction with a number of field experiments and also in special experiments on residue weathering. The methods used will be described in a later section.

\section{TREATMENT OF CROP PLANTS}

Cucumber Field in Mid-Pacific Experimental Area. A 2-acre field in the Mid-Pacific experimental field of the University of Hawaii was used for melon-fly-control experiments. By coöperative arrangement with the Department of Vegetable Crops, about one tenth of this field, or $1 / 5$ acre, was planted to cucumbers on August 23, 1950; tomato plants were set out on the rest of the field on the same date.

The cucumbers were the first to require treatment because the melon fly oviposits in the stems of the very young plants and the larvae develop in these stems. A small percentage of the plants were injured in this manner by September 26, when the treatment program was begun. The field was too small for replicated plots. It was divided into 15 plots of 4 rows each, 14 plots to be treated with sprays or dusts and 1 to be left untreated as a check. All the insecticides used were proprietary formulations. The materials and dosages (expressed as actual toxicant) used in the first treatment were as follows:

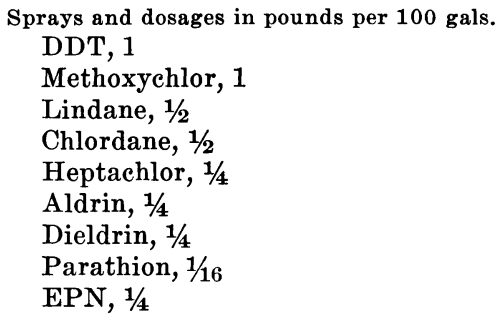

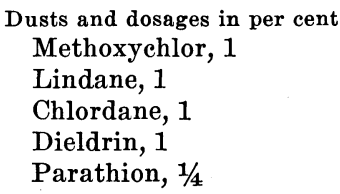

Two further applications were made, on October 3 and 13 ; the same materials were used but the dosages of insecticide were increased by 50 per cent. The dosages were the maximums known to be tolerated by the crops. There was no important injury to the plants or fruit except in the plot dusted with lindane. This dust contained 27 per cent sulfur, which probably was responsible for the injury, since cucumbers are sensitive to it.

In all applications, the east two rows of each plot were treated thoroughly on both upper and under sides of the leaves and the west two rows on the upper sides only. Sprays were applied with a 50-gallon power sprayer delivering 6 gallons per minute with a pressure of 400 pounds. A Monarch spray nozzle was used on a $43 / 4$-foot rod. In the first application 10 gallons of spray was applied per plot, in the two later ones, 15 gallons. Dusts were applied with the equipment described earlier.

Three sleeve cages were placed over branches of vines in each treated plot and one in the check plot. Fifty melon flies per eage were introduced 1 day after the first treatment. Counts made 48 hours after placing the flies in the cage showed 39 flies alive in the check-plot cage, the remainder having evidently been killed and removed by ants. There was a complete kill in all the treated plots except for the following: in the rows treated thoroughly, 
1 survivor in the DDT-sprayed plot and 15 in the methoxychlor-dusted plot; in the rows treated on the upper side of the leaves only, 1 survivor in the dieldrin-sprayed plot, 9 in the DDT-sprayed plot, and 16 in the methoxychlordusted plot.

Fifty flies were again placed in each cage 7 days after the second treatment. Counts were made 24 hours later. There was an average of 29.8 survivors per cage in the treated plots, ranging from 11 to 39 , and 33 in the check plot. These data suggest that there was little effect from the residues a week after treatment. This was confirmed by laboratory cage tests (p. 584), which showed no evidence of kill from week-old residues on cucumber fruits from this field.

On October 13, at the time of the third spraying, practically all cucumbers on the vines had been damaged by oviposition by the melon flies; the treatments were a failure. Since sleeve-cage tests showed that the majority of the residues gave a 100 per cent kill of files confined with the treated foliage for 48 hours beginning on the day after treatment, the ineffectiveness of the crop treatments with insecticides was probably due to the fact that the flies contact the host crop only to oviposit, then leave the field. The period they spend on the host crop appears to be too brief to allow for sufficient "pick-up" of insecticide.

Tomato Field on Poamoho Experiment Farm. At the University of Hawaii Experiment Station grounds at Poamoho, a 1/2-acre tomato field was secured for treatment that was isolated from other cultivated fields except for the field on its east side which was planted to blue indigo, a forage crop. Four invaginated glass traps ${ }^{4}$ were set out to obtain some measure of the abundance of melon flies in the field before treatment. At that time practically all the ripening tomatoes were infested with melon-fly larvae. The first crop of tomatoes was ready for picking, but was left on the vines, and formed a reservoir of enormous numbers of flies for the future.

On October 2, about two thirds of the field was sprayed with parathion wettable powder, $1 / 2$ pound actual toxicant to 100 gallons, and the remainder with dieldrin wettable powder at 1 pound actual toxicant to 100 gallons. The spraying was done with a 400-gallon sprayer with good capacity and pressure. A spray gun was used and the spray stream was directed horizontally against the plants, but from one direction only. The upper sides of all leaves were covered with spray and many leaves were turned by the force of the spray stream and consequently were wetted on both sides. The fruits were also fairly well covered by the spray and the major part of the surface of every fruit had a coating of insecticide.

On October 12, about a third of the tomato plants sprayed on October 2 with parathion were sprayed with EPN wettable powder, 1 pound actual toxicant to 100 gallons, and the remainder, including those previously sprayed with dieldrin, were sprayed with parathion, 1 pound to 100 gallons. Then on October 23 the entire tomato field was sprayed with EPN wettable powder at 2 pounds actual toxicant to 100 gallons.

4 The traps contained a lure consisting of 120 grams raw sugar, $13 \mathrm{ml}$ white vinegar, 1/2 cake of Fleischmann's yeast and water to make 1 liter of solution. This solution will be referred to as "fermenting lure." 
The four glass traps were kept in the tomato field throughout the period of the experiment. At first the common "fermenting lure" was used. Beginning on October 8 , however, the flies were lured to the traps by means of Lederplex vitamin B complex capsules, 15 to 1 liter of water. These capsules were recommended by Mr. Paul Gow of the United States Department of Agriculture. It was found that this lure captured on the average about twice as many flies as the fermenting lure used previously, and this should be borne in mind in comparing the trap catches shown in Table 1.

TABLE 1

TRAP CATCH OF MELON FLIES IN A TOMATO FIELD AT POAMOHO WITH CROP-FIELD SPRAYING

\begin{tabular}{|c|c|c|c|c|c|c|}
\hline $\begin{array}{c}\text { Date } \\
\text { sprayed } \\
(1950)\end{array}$ & $\begin{array}{l}\text { Insecticide and } \\
\text { actual toxicant } \\
\text { per } 100 \text { gals. }\end{array}$ & Period traps set & Lure used & $\begin{array}{l}\text { Flies per } \\
\text { trap-day }\end{array}$ & $\begin{array}{l}\text { Per cent } \\
\text { females }\end{array}$ & $\begin{array}{l}\text { Per cent } \\
\text { females } \\
\text { gravid }\end{array}$ \\
\hline $\begin{array}{l}\text { Before } \\
\text { spraying }\end{array}$ & & Sept. 29 to Oct. 2 & Fermenting & 4.3 & . & $\ldots=$ \\
\hline Oct. 2 & $\begin{array}{l}\text { Parathion, } 1 / 2 \mathrm{lb} . ; \text { or dieldrin, } \\
1 \mathrm{lb} \ldots \ldots \ldots \ldots \ldots \ldots \ldots \ldots\end{array}$ & $\left\{\begin{array}{l}\text { Oct. } 2 \text { to } 8 \\
\text { Oct. } 8 \text { to } 11\end{array}\right.$ & $\begin{array}{l}\text { Fermenting } \\
\text { Vitamin B }\end{array}$ & $\begin{array}{r}1.6 \\
14.0\end{array}$ & 74 & $\begin{array}{l}. . \\
32\end{array}$ \\
\hline Oct. 12 & Parathion, $1 \mathrm{lb}$; or EPN, $1 \mathrm{lb}$. & $\left\{\begin{array}{l}\text { Oct. } 12 \text { to } 16 \\
\text { Oct. } 16 \text { to } 23\end{array}\right.$ & $\begin{array}{l}\text { Vitamin B } \\
\text { Vitamin B }\end{array}$ & $\begin{array}{r}17.5 \\
5.4\end{array}$ & $\begin{array}{l}71 \\
53\end{array}$ & $\begin{array}{l}28^{*} \\
\cdots\end{array}$ \\
\hline Oct. 23 & EPN, 2 lbs... & Oct. 23 to 26 & Vitamin B & 7.3 & 68 & 67 \\
\hline
\end{tabular}

* Based on an examination of 43 females.

On November 11, 1950, 19 days after the third spraying (with 2 pounds actual EPN to 100 gallons), 100 ripe tomatoes were picked and examined in the field, and only 2 contained maggots. Yet before the first treatment it was difficult to find an uninfested tomato anywhere in the field. Although, as shown in the above table, some of the fly catches after the spray program had begun were larger than the fly catch prior to the first spray, nevertheless the spray program apparently gave almost complete protection of the fruit against infestation. Admittedly, however, the insecticide concentrations were excessive from considerations of public health and plant tolerance. Two pounds of actual EPN to 100 gallons resulted in epinasty of the leaves. In view of the continued catch of gravid flies in the traps it is likely that the insecticides acted as a hindrance to oviposition. When 50 gravid females were confined in the laboratory with tomato fruits picked from the field after the third spraying, no oviposition took place although the flies crawled over the fruits for hours before they all succumbed to the residue. Likewise Holdaway (1945) found in laboratory experiments that a 2 per cent DDT dust prevented oviposition on approximately half-grown cucumbers.

On November 13, the field was sprayed with EPN wettable powder at 6 pounds of actual toxicant to 100 gallons of spray. This is of course far in excess of what would be either economically feasible or tolerated by the tomato vines, but was used in an effort to determine whether the fly population could be reduced by extreme concentrations. Six flies were captured in the four traps during a four-day period following treatment. 


\section{TREATMENT OF CORN BORDERS}

Experiment with Cucumbers at Mid-Pacific. The initial experiments with about a fifth of an acre of cucumbers in the University of Hawaii's MidPacific farm area, previously described, demonstrated that thorough weekly treatments with either sprays or dusts at the maximum concentrations tolerated by cucumbers were not sufficient to prevent a total loss of the crop.

Two rows of corn, about 6 feet apart, had been planted around the 2-acre field of which the cucumber patch formed a small section at the west end. Between the two rows of corn was a row of pigeon peas. Pigeon-pea plants also attract melon flies and have the advantage of remaining green longer than corn. At first the pigeon pea appeared to have still another advantage. It was noted that insecticides deposited by spraying remained on the under sides of the leaves in greater quantity and for longer periods than on the under sides of corn leaves. However, the dense pubescence on the under side of the leaf makes it difficult for the tarsi of the flies to come in contact with the insecticide residues and as a result the latter are not as effective as they are on corn leaves. Pigeon peas were not used in subsequent experiments.

After the failure of the attempts to control the melon flies by the treatment of the cucumber vines, the corn and pigeon-pea border was divided into three sections sprayed respectively with parathion, EPN, and dieldrin wettable powders. Parathion was used at 2 pounds and the other two at 3 pounds of actual toxicant to 100 gallons. Less parathion was used because it appeared to be more toxic to corn foliage than the other insecticides. High concentrations of toxicant were used because frequent rains removed much insecticide even on the under sides of the leaves, and it was thought that by using a high concentration, sufficient insecticide might remain over a period of a week to kill the flies resting on the corn leaves. The low gallonage used in spraying the borders only, as compared to that which is required to spray the entire field, might make the use of such high concentrations of insecticide economically feasible. Spray applications to both upper and under sides of the leaves were made once a week. In all treatments, approximately 300 gallons of spray were used to treat the corn and pigeon-pea border that surrounded the 2 -acre field.

The first spraying of the entire corn border was done on October 18, 1950. Seven invaginated glass traps with fermenting lure were placed in the cucumber patch 2 days before treatment. These traps captured 346 flies in the 2-day period, an average of 49.4 per trap. Sixty-one per cent of the flies were females. After the first corn-border spraying, only 1 trap was left in the cucumber patch and 3 were placed in the tomato patch that made up the major portion of the 2-acre field. Over a 6 -day period after treatment only 1 fly was caught in the trap left in the cucumber patch.

It was obvious that the corn-border spraying had resulted in an almost complete elimination of melon flies from the cucumber patch. An effort was made to determine the immediate effect of this drastic reduction in the fly population on the per cent infestation of cucumbers.

Table 2 shows that the per cent of uninfested fruit increased from 0.25 
before spraying to 53 one week after the first spraying and to 671 week after the second spraying. During this two-week period the average number of egg punctures ("stings") per fruit was reduced from over 8.89 to 1.42. In Honolulu cucumbers with only a few stings are marketable, especially if they constitute only a small percentage of the total number of fruits in a given lot. The per cent of infested fruit with 2 "stings" or less increased from 5 before spraying to 91 one week after the second spraying. Thus the control from an economic standpoint is greater than that which is indicated by the per cent of uninfested fruits.

TABLE 2

\section{EFFECT OF CORN-BORDER SPRAYING ON MELON-FLY INFESTATION OF CUCUMBERS}

Sprayed with parathion wettable powder at 2 pounds or EPN or dieldrin wettable powder at 3 pounds toxicant to 100 gallons

\begin{tabular}{|c|c|c|c|c|c|}
\hline \multirow{2}{*}{ Date sprayed, 1950} & \multirow{2}{*}{$\begin{array}{c}\text { Date } \\
\text { exam- } \\
\text { ined. } \\
1950\end{array}$} & \multicolumn{2}{|c|}{ Fruits with "stings" } & \multirow{2}{*}{$\begin{array}{l}\text { Average } \\
\text { "stings" } \\
\text { per fruit }\end{array}$} & \multirow{2}{*}{$\begin{array}{c}\text { Per cent } \\
\text { uninfestec } \\
\text { fruit }\end{array}$} \\
\hline & & $\begin{array}{c}\text { Total } \\
\text { number }\end{array}$ & $\begin{array}{c}\text { Per cent } \\
\text { with } 0 \text { to } 2 \\
\text { "stings" }\end{array}$ & & \\
\hline Before spraying...... & Oct. 16 & 789 & 5.3 & $8.89^{*}$ & 0.25 \\
\hline 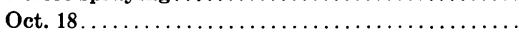 & Oct. 25 & 537 & 79.9 & 1.60 & 53.25 \\
\hline 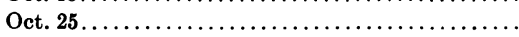 & Nov. 1 & 753 & 90.8 & 1.42 & 67.33 \\
\hline
\end{tabular}

* In addition, 9.25 per cent of the cucumbers were so rotted that oviposition punctures could not be counted. The rotted cucumbers usually had the greatest number of "stings."

First Experiment with Tomatoes at Mid-Pacific. When the corn border of the 2-acre field referred to above was first treated on October 18, 1950, the tomatoes were beginning to ripen, and it appeared that practically all ripening fruits were infested. Many of the small fruits were also stung, but the larvae do not develop in fruits that have not reached a certain degee of maturity.

The infested fruits were allowed to rot and drop to the ground. This must have increased the fly population greatly in comparison to what it would have been if the fruit had been removed from the field. Nishida and Bess (1950) showed that sanitation itself, with no insecticide treatment, may result in a fair degree of control in isolated fields.

No estimate of the reduction in per cent of stung 'or infested tomatoes could be made until the fruit stung or infested previous to the first border spraying had all rotted or dropped from the vines so that the subsequent fruit could be readily distinguished. In the meantime the only criterion of the effectiveness of the spraying was the extreme reduction in fly population as indicated by the trap catch.

Table 3 shows the insecticides used and the eatch of flies from 4 glass traps, 3 in the section of the 2 -acre field planted to tomatoes and 1 in the section planted to cucumbers. The latter was moved to the west end of the tomato field on November 1, for the cucumber vines were drying up and were being covered with weeds. One spraying of the corn border reduced the total fly catch from 104 for a 3-day period to 0 for a 6-day period. After 
the second spray, 2 flies were caught in a period of 6 days. On November 1,1950 , in place of the third spray, a Lawrence mist blower was used to treat the corn border. The insecticides were 25 per cent parathion wettable powder at 0.24 per cent toxicant, 25 per cent aldrin wettable powder at 0.24 per cent toxicant, methoxychlor-kerosene emulsion with 0.48 per cent toxicant, and cubé-root kerosene emulsion with 0.06 per cent rotenone. The nozzle was adjusted for a maximum discharge of liquid, so a greater volume was blown into the field than would be normal with this type of equipment. By driving completely around the 2-acre field and blowing the mist inward

TABLE 3

TRAP CATCH OF MELON FLIES IN A TOMATO FIELD AT MID-PACIFIC WITH CORN-BORDER, TREATMENT

\begin{tabular}{|c|c|c|c|c|}
\hline Treatment & $\begin{array}{c}\text { Date } \\
\text { treated } \\
(1950)\end{array}$ & Insecticide and actual toxicant per 100 gals. & $\begin{array}{c}\text { Period traps } \\
\text { set }\end{array}$ & $\begin{array}{l}\text { Flies per } \\
\text { trap-day }\end{array}$ \\
\hline None & & Parathion or EPN, 2 lbs.; or dieldrin, 3 lbs.. & Oct. 14 to 17 & 34.7 \\
\hline First spray & Oct. 18 & Parathion or EPN, 2 lbs.; or dieldrin, 3 lbs... & Oct. 19 to 25 & C.0 \\
\hline Second spray & Oct. 25 & Parathion or EPN, 2 lbs.; or dieldrin, $3 \mathrm{lbs} . .$. & Oct. 26 to 31 & 0.4 \\
\hline Space spray* & Nov. 1 & Various mist sprays ${ }^{*} \ldots \ldots \ldots \ldots \ldots \ldots \ldots \ldots$ & Nov. 2 to 7 & 14.6 \\
\hline Third spray & Nov. 7 & Dieldrin, 3 lbs................... & Nov. 7 to 12 & 1.0 \\
\hline Fourth spray & Nov. 22 & EPN or dieldrin, 2 lbs. . & Nov. 23 to 28 & $3.2 \dagger$ \\
\hline
\end{tabular}

\footnotetext{
* Concentrated mixtures of various insecticides (see text) applied with a Lawrence mist blower so as to give a 100 per cent kill.

$\dagger$ The corn border at the west side of the field had been plowed under, thus reducing the effectiveness of the entire corn border. The luxuriant growth of weeds also probably contributed to the increase in the fly population.
}

on to the corn border and into the tomato planting, a total of 30 gallons of liquid was used. An appreciable amount of residue was deposited on the corn, but much less than would be deposited by a conventional spray. In addition the coverage was far from complete, especially on the lower sides of the leaves. This treatment may be considered to be a space treatment.

For each of the four insecticides used in the mist sprays, one small screen eage with 25 melon flies and supplied with food and water was suspended on a stake within the two rows of corn and one was placed in the same manner about 20 feet inside the tomato field. In all 8 cages there was a 100 per cent mortality of the flies within 24 hours; as a space spray the treatment was effective. The flies in the cages suspended in the corn died within a few hours, showing that there was much more insecticide present than was required to obtain a 100 per cent kill.

The results of the treatment are shown in Table 3. After the space treatment the fly population from the 4 traps increased from 2 to 73 . A conventional spray treatment the following week reduced the 5-day catch again to 5 flies. This spray, applied on November 7 , consisted of 25 per cent dieldrin wettable powder at 3 pounds of toxicant to 100 gallons. The fourth (conventional) spray was not applied until November 22.

Two hundred ripe tomatoes picked at random were examined 3 weeks after the date of the first corn-border treatment and none of these contained oviposition marks, eggs, or larvae of the melon fly. In addition, inquiries were made of a number of families that were constantly consuming tomatoes 
from the protected field throughout the season and none had found melonfly larvae in the tomatoes that ripened after treatment began.

Second Experiment with Tomatoes at Mid-Pacific. The above field was plowed under and was again planted to tomatoes on January 9, 1951. This time the 2-acre area was divided into two fields, each completely surrounded by a double row of corn border. The corn was planted on December 28, 1950.

TABLT 4

THE MOVEMENT OF MARKED MELON FLIES BETWEEN TWO ADJACENT TOMATO FIELDS*

Each Field Surrounded by Corn Borders

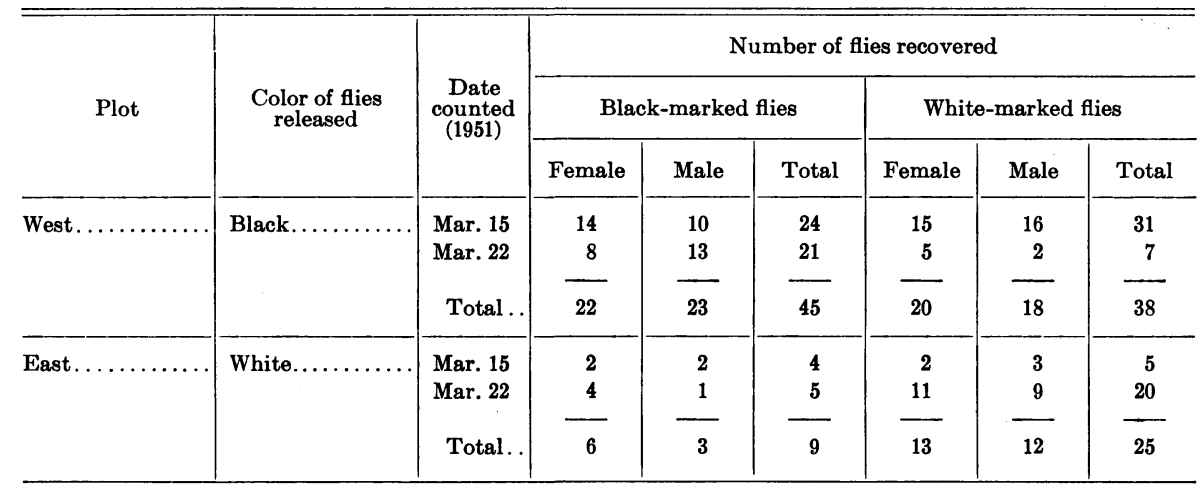

* The marked flies were released on March 9 and March 16, 1951. Four McPhail traps with fermenting lure were placed in each field and the figures in the table represent the catch for a 24-hour period with traps set 5 days after release of the flies.

A 20-foot space divided the outer rows of corn of the two fields. It was hoped that the flies might remain within the separate fields so that different treatments in the two fields might be compared, even though they were only 20 feet apart.

Because the fly population at the beginning of the experiment was very low, 1,000 marked flies were liberated in each of the two fields on March 9, 1951. The flies were anesthetized and a dot was placed on the thorax of each, a black dot on those liberated in the west field and a white one on those liberated in the east field. The same number of flies, marked in the same way, were liberated in the two fields again on March 16. Four McPhail traps were placed in each field. The catch of marked flies after liberation is shown in Table 4. Note that in the west field among the flies liberated on March 9 and trapped on March 15, there were more white-marked flies than blackmarked flies recaptured, even though the former were liberated in the east field. The marked migration of flies from the east field to the west field precluded the possibility of an accurate comparison of treatments. There was considerably less tendency of flies to move from the west field to the east field than vice versa. The data imply that many flies from the west field must have migrated still further west. In fact, one black-marked fly was caught in a trap $1 / 3$ mile southwest of this field. 
The corn border of the west field was sprayed with 25 per cent parathion wettable powder at 0.27 pound of actual toxicant to 100 gallons applied twice a week and that of the east field with 50 per cent DDT wettable powder at 4 pounds of actual toxicant to 100 gallons applied once a week. The difference in the frequency of spraying was due to the difference in the weathering properties of parathion and DDT residues.

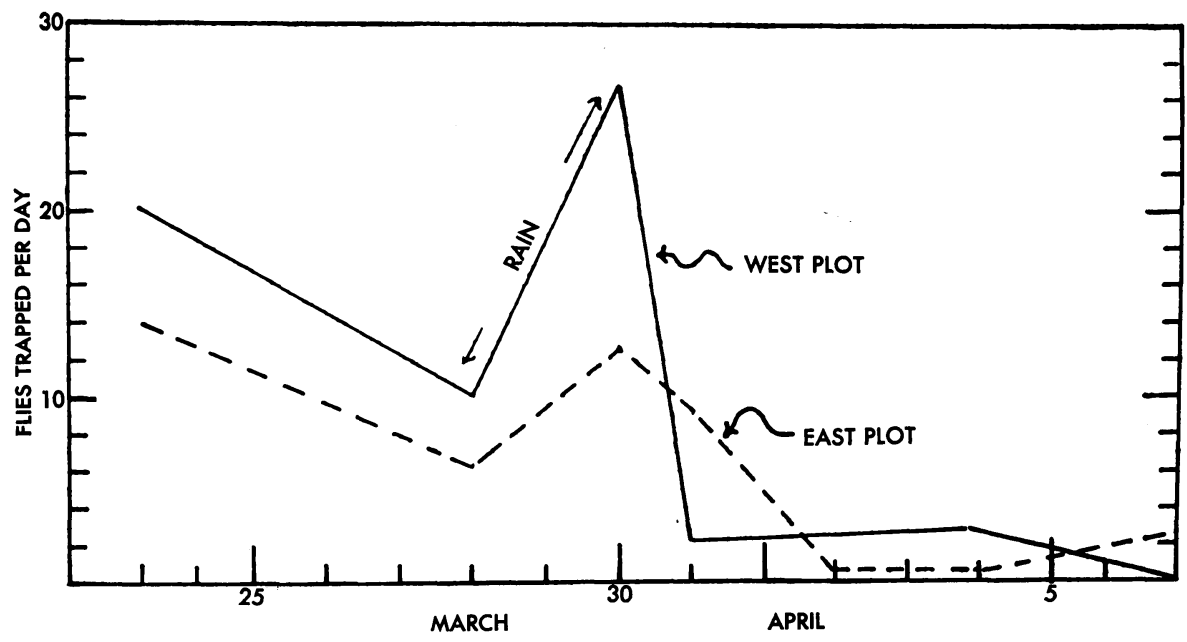

Fig. 1. Fluctuation of the melon-fly population in the west plot, the corn border of which was sprayed with parathion, and the east plot, the corn border of which was sprayed with DDT, in the Mid-Pacific tomato field. Sprays were applied in both plots on March 23, March 30, and April 7, 1951. The west plot was also sprayed on March 27 and April 3.

The corn borders of both fields were sprayed March 23, March 30, and April 7. The west-field border was also sprayed March 27, April 3, and April 11. The spray program was continued to April 21, but the results after the spraying of April 7 are not given because, as is shown in Figure 1, the fly population was extremely low in both fields. An additional point of interest is the sudden rise in the fly population after the trap count of March 28. This is especially noticeable in the west plot, which was sprayed with parathion. The rise in the fly population may have been associated with an extremely heavy rainstorm which occurred on March 27 and 28, which brought a total of 7.1 inches of rain. The rain almost completely removed the visible insecticide residue from the corn foliage in the west plot, which was sprayed with parathion, while the corn in the east plot, sprayed with DDT, retained considerable visible residue on the under sides of the leaves despite the rain. The greater resistance of DDT to removal by rain may be explained by its extremely low water solubility, as compared to that of parathion. While the solubility of parathion in water is 20 parts per million, the true solubility of DDT in water is only 0.0002 part per million, although it can form colloidal solutions up to 0.2 part per million, according to Brown (1951). 
Comparisons between treatments are probably unwarranted due to the demonstrated migration of the flies in the experimental area.

Because of a severe wilt infection and prolonged periods of rain, the crop was a total loss and no check could be made on the fly infestation.

Experiment with Tomatoes at Waimanalo. At the University of Hawaii Agricultural Experiment Station farm at Waimanalo, a field of tomatoes 50 feet wide and 400 feet long had a single row of corn planted along its south border while along its north border the corn extended only about half the distance of the field. At the east and west sides of the field no corn was planted but there was a hibiscus hedge along the east border and it was later found that many flies rested in this hedge.

Four glass traps were spaced at equal distances apart along a median line in this narrow tomato field. In a 3 -day period prior to treatment the traps caught 136 melon flies (81 males and 55 females). Of 20 females examined, 7 were gravid.

For the first treatment on October 30, 1950, the under sides of a few leaves on each corn plant were painted by means of a paint brush with a suspension containing a high concentration of EPN (the equivalent of 6 pounds of actual toxicant to 100 gallons). The suspension also contained 100 Lederplex vitamin B capsules per gallon. Despite the fact that hundreds of dead flies could be found under the cornstalks, the next 3-day trap catch yielded 72 melon flies. A near-by melon field had been plowed under and flies that had previously inhabited that field were now migrating to the tomato field and increasing the difficulty of the control.

The next treatment was a spray consisting of 25 per cent parathion wettable powder at 2 pounds of actual toxicant to 100 gallons applied on November 4,1950 , with good coverage of the under sides of leaves. The wind was blowing briskly and a light spray was allowed to drift over the tomato field. Flies were falling to the ground from the corn plants by the hundreds within 30 minutes and no flies could be found in the field. The following day no live flies could be found either on the corn border or on the tomato plants. Fermenting lure was added to the traps again on November 5. Three days later the flies were abundant again and the four traps yielded 141 flies. Although there had been a few showers of rain, apparently some parathion residue remained on the under side of the leaves, for flies were dropping from the cornstalks continuously over the 3-day period. However, the fly population in the tomato field remained at a high level.

On November 10 the treatment was the same as on November 4 , and the subsequent 4-day trap catch was 63 melon flies. On November 14 the corn was sprayed with methoxychlor wettable powder, 4 pounds of actual toxicant to 100 gallons. In 4 days the trap catch increased to 410 flies.

On November 20 the corn was sprayed with 25 per cent dieldrin wettable powder at 3 pounds of actual toxicant to 100 gallons. The subsequent 4-day trap catch was 82 . Thus over the 25 -day period of the experiment the melonfly population had been reduced from 11.3 to 5.1 per trap-day.

No more treatments were made, and on December 6 the traps were again set out for a period of 2 days. They caught 319 melon flies (123 males and 196 females), making a trap-day average of 34.9 flies. 
Although over the 25-day period of the experiment the fly catch decreased from 11.3 to 5.1 per day, this reduction was not sufficient to prevent serious damage to the tomatoes in this field. Several factors are suggested as being responsible for the inadequate control: (1) the field was small and the percentage of fruit infested was correspondingly high as compared to what it

TABLE 5

NUMBER OF MELON FLIES CAUGHT IN CORN BORDER AND IN CUCURBIT FIELD, WAIMANALO*

\begin{tabular}{|c|c|c|c|c|c|c|c|c|}
\hline \multirow[b]{2}{*}{$\begin{array}{c}\text { Date traps examined } \\
(1951)\end{array}$} & \multicolumn{4}{|c|}{ Traps in corn border } & \multicolumn{4}{|c|}{ Traps in cucurbit field } \\
\hline & $\begin{array}{l}\text { Gravid } \\
\text { females }\end{array}$ & $\begin{array}{c}\text { Non- } \\
\text { gravid } \\
\text { females }\end{array}$ & Males & $\begin{array}{l}\text { Flies } \\
\text { per trap- } \\
\text { day }\end{array}$ & $\begin{array}{l}\text { Gravid } \\
\text { females }\end{array}$ & $\begin{array}{l}\text { Non- } \\
\text { gravid } \\
\text { females }\end{array}$ & Males & $\begin{array}{l}\text { Catch } \\
\text { per trap- } \\
\text { day }\end{array}$ \\
\hline Mar. $30 \ldots \ldots \ldots \ldots \ldots$ & 0 & 0 & 1 & $0.2 \dagger$ & 8 & 12 & 9 & 7.2 \\
\hline Apr. $3 \ldots \ldots \ldots \ldots \ldots \ldots$ & 1 & 2 & 1 & 0.7 & 1 & 2 & 6 & 1.1 \\
\hline$\ldots \ldots \ldots \ldots \ldots$ & 1 & 1 & 4 & 0.8 & 1 & 1 & 0 & 0.3 \\
\hline$\ldots \ldots \ldots \ldots \ldots$ & 1 & 3 & 0 & 0.5 & 2 & 0 & 0 & 0.2 \\
\hline Apr. $13 \ldots \ldots \ldots \ldots \ldots$ & 3 & 0 & 0 & 0.5 & 1 & 1 & 0 & 0.3 \\
\hline Apr. $17 \ldots \ldots \ldots \ldots \ldots$ & 0 & 0 & 0 & 0.0 & 1 & 0 & 0 & 0.1 \\
\hline Apr. $20 \ldots \ldots \ldots \ldots \ldots$ & 0 & 0 & 2 & 0.3 & 2 & 0 & 0 & 0.3 \\
\hline Apr. 23. & 0 & 1 & 1 & 0.3 & 1 & 0 & 1 & 0.3 \\
\hline Apr. 27... & 4 & 0 & 3 & 1.0 & 0 & 0 & 0 & 0.0 \\
\hline May $1 \ldots$ & 1 & 3 & 2 & 0.8 & 1 & 6 & 3 & 1.2 \\
\hline May $5 \ldots$ & 4 & 10 & 10 & 3.0 & 6 & 5 & 4 & 2.0 \\
\hline May $9 \ldots$. & 0 & 2 & 2 & 0.5 & 0 & 3 & 2 & 0.6 \\
\hline May $11 \ldots \ldots \ldots \ldots$ & 2 & 2 & 2 & 1.5 & 1 & 0 & 3 & 1.0 \\
\hline May $15 \ldots \ldots \ldots \ldots$ & 1 & 3 & 2 & 0.8 & 1 & 4 & 3 & 1.0 \\
\hline May $19 \ldots \ldots \ldots \ldots$ & 2 & 1 & 0 & 0.4 & 0 & 6 & 3 & 1.1 \\
\hline May $23 \ldots$ & 4 & 4 & 3 & 1.4 & 3 & 3 & 2 & 1.0 \\
\hline May $26 \ldots \ldots \ldots \ldots \ldots$ & 3 & 1 & 1. & 1.0 & 1 & 4 & 1 & 1.0 \\
\hline May $30 \ldots \ldots \ldots \ldots \ldots$ & 2 & 0 & 1 & 0.4 & 1 & 1 & 0 & 0.2 \\
\hline June $2 \ldots \ldots \ldots \ldots \ldots$ & 4 & 4 & 5 & 2.1 & 0 & 1 & 0 & .0 .2 \\
\hline June $6 \ldots \ldots \ldots \ldots \ldots$ & 5 & 1 & 10 & 2.0 & 1 & 0 & 2 & 0.4 \\
\hline
\end{tabular}

* The corn border was sprayed twice a week starting March 30, 1951, using parathion wettable powder at $1 / 2$ pound of toxicant to 100 gallons up to April 20, when the concentration was reduced to $1 / 4$ pound to 100 gallons, dieldrin wettable powder at 1 pound of toxicant to 100 gallons on May 1 and May 5, and DDT wettable powder at 4 pounds of toxicant to 100 gallons on May 9 and 2 pounds to 100 gallons from May 11 to May 26 . Two invaginated glass traps were kept in the corn border and 2 in the cucurbit field.

$\dagger$ The corn had not reached sufficient height to attract the flies.

would be with the same number of flies in a field of average size; (2) no control was practiced on near-by infested host crops ; (3) an adjoining melon field was plowed under and the flies formerly infesting that field moved to the experimental tomato field; and (4) probably many melon flies were attracted into the field by the bait traps. The importance of the fourth factor is shown by the high proportion of males and nongravid females; these would ordinarily constitute only about 10 per cent of the fly population in a tomato field (Nishida and Bess, 1950).

Experiment with Cucurbits at Waimanalo. The above narrow field was planted to various cucurbits (cucumbers, watermelons, cantaloupes, squashes, and pumpkins) early in March, 1951, and a double row of corn was planted completely around the field. Beginning on March 30, when the corn border was 6 inches tall, it was sprayed twice a week with a spray containing 25 
per cent parathion wettable powder at $1 / 2$ pound of toxicant per 100 gallons. Again the spray was applied to both lower and upper sides of the leaves. The concentration of parathion wettable powder was reduced to $1 / 4$ pound of toxicant on April 20. Then on May 1 the treatment was changed from parathion to 25 per cent dieldrin wettable powder at 2 pounds of toxicant to 100 gallons. On May 9 a 50 per cent DDT wettable powder at 4 pounds of toxicant per 100 gallons was substituted for the dieldrin. On May 11 a program of treatment was begun that was continued to the last spraying on May 26. This consisted of 50 per cent DDT wettable powder at 4 pounds of actual toxicant to 100 gallons applied twice a week.

Two glass traps with fermenting lure were placed in the corn border and two in the cucurbit field. Table 5 shows the average number of flies caught per day in the corn border and in the crop field for the 2 days preceding the first spraying of the corn border and at semiweekly intervals thereafter.

The trap records for a 2-day period prior to the first spraying show that the pretreatment fly population was extremely low. However, the corn was only 6 inches high and had been flattened out to the ground by a record rain and windstorm and probably did not attract many flies. The trap catch remained low throughout the entire period of the experiment.

As stated previously, the crop consisted of a wide variety of cucurbits. Half a dozen cucumber vines were the first to have fruit. Despite the relatively low fly population, practically all of the first cucumbers to develop were attacked by flies. Later, squash, pumpkins, watermelons, muskmelons and a variety of wild cucurbits produced fruits in large numbers. Four samples of squashes and one of cucumbers were examined on April 23 and a similar set on May 10. The percentage of fruits less than 4 inches long "stung" by melon flies was 52.5 on April 23 and 19.2 on May 10. As can be seen from Table 5, this reduction in percentage of "stung" fruits was not correlated with a reduction in the melon-fly population. The number of fruits in the field had greatly increased, however, so that the percentage attacked by the limited number of flies present was reduced. This is a tendency that is particularly noticeable in small fields such as the one in question.

Experiment with Watermelons at Lualualei. An experiment was made in a 3-acre watermelon field in Lualualei Valley, near Waianae. The melons were planted on January 3, 1951, and on the same day a double-row corn border was planted around about a $1 / 2$ acre of the field at its east end.

Beginning February 17, when the melons had begun to put out runners and the corn was about 18 inches high, the corn border was sprayed once a week with 25 per cent parathion wettable powder at 2 pounds of toxicant to 100 gallons. For the first application, the parathion was applied only to the under sides of the leaves and an equivalent concentration of dieldrin, used as a wettable powder, was applied to the upper sides of the leaves. Subsequently only the parathion spray was used, applied to both sides of the leaves.

The remainder of the field-about $2 \frac{1}{2}$ acres-was sprayed by the owner with 25 per cent parathion wettable powder at a concentration of 0.5 pound of toxicant to 100 gallons. He used a 325-gallon power sprayer that had a 40-foot boom with nozzles spaced 1 foot apart. The watermelons were planted 
in 80-foot strips so that an entire strip could be sprayed by driving the spray rig along the windward side of the field, with the boom in a vertical position. The spray was blown by the wind over the entire field.

Table 6 shows the results of the semiweekly counts of flies in 8 glass traps. In the field inside the corn border, 2 traps were placed between the two

TABLE 6

\section{TRAP CATCH OF MELON FLIES IN A WATERMELON FIELD AT LUALUALEI}

In a Plot with a Treated Corn Border and in a Treated Plot Outside the Border*

\begin{tabular}{|c|c|c|c|c|c|c|c|c|c|c|}
\hline \multirow{3}{*}{$\begin{array}{c}\text { Date traps examined } \\
(1951)\end{array}$} & \multicolumn{4}{|c|}{ Flies per trap-day } & \multicolumn{3}{|c|}{$\begin{array}{c}\text { Female flies, per cent } \\
\text { of total flies }\end{array}$} & \multicolumn{3}{|c|}{$\begin{array}{l}\text { Gravid females, per cent } \\
\text { of total females }\end{array}$} \\
\hline & \multicolumn{2}{|c|}{$\begin{array}{l}\text { Plot inside } \\
\text { corn border }\end{array}$} & \multicolumn{2}{|c|}{$\begin{array}{l}\text { Plot outside } \\
\text { corn border }\end{array}$} & \multirow{2}{*}{ Border } & \multirow{2}{*}{$\begin{array}{c}\text { Kiawe } \\
\text { trees }\end{array}$} & \multirow{2}{*}{$\begin{array}{l}\text { Crop } \\
\text { field } \dagger\end{array}$} & \multirow{2}{*}{ Border } & \multirow{2}{*}{$\begin{array}{c}\text { Kiawe } \\
\text { trees }\end{array}$} & \multirow{2}{*}{$\begin{array}{l}\text { Crop } \\
\text { field } \dagger\end{array}$} \\
\hline & Border & $\begin{array}{l}\text { Crop } \\
\text { field }\end{array}$ & $\begin{array}{c}\text { Kiawe } \\
\text { trees }\end{array}$ & $\begin{array}{l}\text { Crop } \\
\text { field }\end{array}$ & & & & & & \\
\hline Feb. 17 . & 56.7 & 63.5 & 127.2 & 74.5 & 53.3 & 50.5 & 64.8 & 41.3 & 35.4 & 44.1 \\
\hline Feb. 19 . & 10.2 & 3.5 & 127.0 & 30.5 & 58.5 & 50.2 & 52.9 & 33.3 & 15.6 & 30.6 \\
\hline Feb. 21 & 39.5 & 34.7 & 347.2 & 150.7 & 81.6 & 38.1 & 57.9 & 7.0 & 11.7 & 14.2 \\
\hline Feb. 24. & 61.5 & 54.3 & 228.1 & 177.3 & 50.4 & 42.6 & 47.8 & 29.6 & 20.4 & 26.0 \\
\hline Feb. 26. & 15.5 & 13.2 & 117.2 & 45.2 & 54.8 & 52.0 & 35.3 & 23.5 & 14.8 & 23.4 \\
\hline Feb. 28 . & 8.2 & 8.5 & 151.0 & 27.2 & 75.8 & 52.6 & 39.1 & 44.0 & 9.4 & 43.5 \\
\hline Mar. 2. . & 11.2 & 2.2 & 95.0 & 16.5 & 53.3 & 51.6 & 53.3 & 54.2 & 9.7 & 35.0 \\
\hline Mar. 5. . & 22.5 & 3.6 & 60.6 & 10.6 & 66.7 & 52.2 & 36.3 & 25.0 & 16.8 & 32.6 \\
\hline Mar. 7... & 16.5 & 6.7 & 58.0 & 60.5 & 45.4 & 48.3 & 46.5 & 40.0 & 17.8 & 12.0 \\
\hline Mar. $10 \ldots$ & 10.3 & 4.5 & 20.1 & 16.3 & 50.0 & 40.5 & 44.8 & 25.8 & 10.2 & 25.0 \\
\hline Mar. $13 \ldots \ldots$ & 2.3 & 2.0 & 26.1 & 8.1 & 35.7 & 47.1 & 45.9 & 40.0 & 23.0 & 50.0 \\
\hline Mar. $17 \ldots \ldots$ & 10.5 & 2.0 & 6.3 & 8.2 & 68.3 & 64.7 & 43.9 & 37.2 & 50.0 & 38.9 \\
\hline Mar. $20 \ldots$. & 2.0 & 0.6 & 8.1 & 4.8 & 33.3 & 44.9 & 51.5 & 25.0 & 18.2 & 23.5 \\
\hline Mar. 24... & 2.3 & 0.7 & 8.2 & 22.7 & 78.9 & 46.9 & 40.2 & 33.3 & 25.0 & 28.2 \\
\hline Mar. 27... & 4.1 & 0.3 & 4.1 & 1.8 & 56.0 & 44.0 & 76.9 & 85.7 & 45.5 & 90.0 \\
\hline Mar. $30 \ldots$ & 22.1 & 3.3 & 15.8 & 9.5 & 60.9 & 55.8 & 57.1 & 46.9 & 47.2 & 47.7 \\
\hline Apr. 3... & 3.5 & 0.5 & 5.6 & 4.0 & 46.4 & 48.9 & 60.7 & 38.4 & 18.2 & 47.0 \\
\hline Apr. $6 \ldots \ldots \ldots \ldots$ & 8.3 & 1.0 & 3.0 & 2.6 & 67.3 & 55.6 & 54.2 & 12.2 & 20.0 & 76.9 \\
\hline Average. . & $\ldots$ & $\ldots$ & $\ldots$ & $\ldots$ & 57.6 & 49.3 & 50.5 & 35.7 & 22.2 & 38.3 \\
\hline
\end{tabular}

* The melon flies were controlled in the corn-border plot by spraying the corn once a week beginning Feb. 17, 1951 , with 25 per cent parathion wettable powder at 2 pounds of toxicant to 100 gals. The melon field outside the corn border was sprayed with 25 per cent parathion wettable powder at 0.5 pound of toxicant to 100 gals. applied 4 times a week if weather permitted.

$\dagger$ Average of plots inside and outside the corn border.

rows of corn and 2 in the melon field about midway between the east and west borders. In the field outside the corn border 2 traps were located in kiawe $e^{5}$ trees about 20 feet beyond the edge of the field on the west end and 2 in the melon field about 50 feet from the west end.

It can be seen from Table 6 that there was an extremely high catch of flies in the melon field and adjacent areas at the time of the beginning of the experiment. The first spraying of the corn border on February 17 greatly reduced the catch of flies: on February 19 the trap catch showed an average of only 10 flies per trap-day in the corn border as compared with 57 during the 2 days before treatment. In the melon field enclosed by the corn border,

\footnotetext{
'Prosopsis chilensis, a fairly large leguminous tree.
} 
the fly catch fell even more sharply to $3 \frac{1}{2}$ per trap-day as compared with $631 / 2$ before treatment. During the next 5 days, however, the fly catch in the corn-enclosed melon field rose to near its pretreatment level. There were very heavy rains on February 19, 20, and 21, and at the time of the second spraying on February 23 most of the visible residue of the first spraying had been removed, even on the under sides of the leaves.

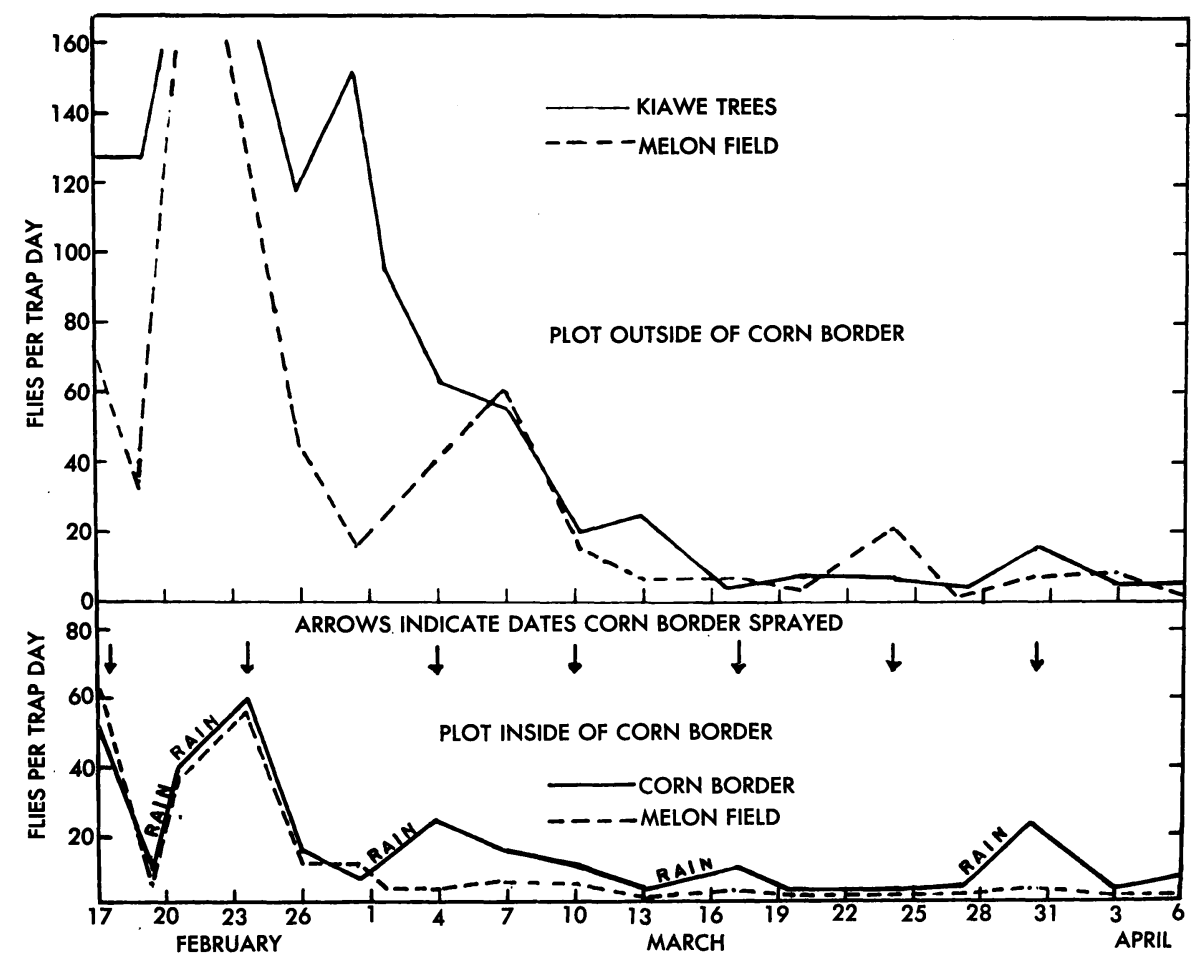

Fig. 2. Fluctuation of the melon-fly population in adjacent watermelon fields, one (below) surrounded by a corn border. The corn border of the latter field was sprayed once a week with parathion. In the plot without a corn border the melon vines were treated four times a week when weather permitted (see text).

All female flies taken from the traps were dissected to determine whether they were gravid. As stated previously, nongravid females and males are ordinarily scarce in a crop field. Their abundance in the traps, as shown in Table 6, again indicates that many flies that would not ordinarily be present are lured into a crop field by the bait traps. Only 38.3 per cent of the females in the traps in the crop field were gravid, and even less in the traps in the border locations. This indicates that the gravid females are less attracted to the traps than are the nongravid females. Consequently the trap catches give a conservative estimate of the benefit of treatment.

As can be seen from Figure 2, the spray of February 23 ended the upward trend in the fly population in the corn and the corn-enclosed melon field and 
brought it down in a manner similar to that of the first spray. During the course of the experiment there were three other periods when the fly population rose appreciably, and in every case the rise was concomitant with a period of heavy showers or rains. The rain of March 26-27, which resulted in the last sharp rise in fly population in the present experiment, also flooded the entire melon field and destroyed the melon vines. However, the trapping of the flies was continued until April 6.

TABLE 7

NUMBER OF MELON FLIES COUNTED IN 3-MINUTE PERIODS ON CORN BORDER AND ON MELONS AT LUALUALEI*

\begin{tabular}{|c|c|c|c|c|c|c|c|c|c|}
\hline \multirow{2}{*}{ Date (1951) } & \multicolumn{8}{|c|}{ Station, corn } & \multirow{2}{*}{$\begin{array}{l}\text { Station } \\
\text { melons }\end{array}$} \\
\hline & 1 & 2 & 3 & 4 & 5 & 6 & 7 & Average & \\
\hline Feb. 14 & 62 & 251 & 230 & 171 & 116 & 122 & 48 & 142.8 & $\ldots$ \\
\hline Feb. 15 & 130 & 224 & 236 & 150 & 143 & 153 & 127 & 167.3 & 6 \\
\hline Feb. 17 . & 112 & 232 & 254 & 164 & 163 & 147 & 124 & 170.8 & 8 \\
\hline Feb. 19 . & 0 & 0 & 0 & 0 & 0 & 0 & 0 & 0.0 & $\ldots$ \\
\hline Feb. 21.. & 16 & 1) & 5 & 2 & 6 & 8 & 10 & 8.1 & $\ldots$ \\
\hline Feb. 23 . & 10 & 13 & 3 & 7 & 7 & 9 & 18 & 9.5 & 4 \\
\hline Feb. 26 . & 0 & 1 & 0 & 0 & 0 & 0 & 0 & 0.1 & 4 \\
\hline Feb. $28 \ldots \ldots \ldots$ & 0 & 4 & 4 & 1 & 1 & 2 & 1 & 1.8 & $\ldots$ \\
\hline Mar. $2 \ldots \ldots \ldots \ldots$ & 0 & 1 & 1 & 0 & 0 & 0 & 0 & 0.3 & 2 \\
\hline Mar. $5 \ldots \ldots \ldots \ldots$ & 0 & 0 & 0 & 0 & 0 & 0 & 0 & 0.0 & 0 \\
\hline Mar. $7 \ldots \ldots \ldots \ldots$ & 2 & 5 & 3 & 3 & 2 & 0 & 0 & 2.1 & $\mathbf{5}$ \\
\hline Mar. $9 \ldots \ldots \ldots \ldots$ & 2 & 4 & 0 & 0 & 1 & 1 & 2 & 1.4 & 5 \\
\hline Mar. $13 \ldots \ldots \ldots \ldots$ & 4 & 12 & 8 & 9 & 7 & 2 & 4 & 6.7 & 2 \\
\hline Mar. $16 \ldots \ldots \ldots \ldots$ & 1 & 5 & 7 & 5 & 5 & 7 & 7 & 5.4 & 4 \\
\hline Mar. $20 \ldots \ldots \ldots \ldots$ & 0 & 0 & 0 & 0 & 0 & 0 & 1 & 0.1 & 3 \\
\hline Mar. $23 \ldots \ldots \ldots$ & 6 & 7 & 6 & 11 & 4 & 2 & 4 & 5.7 & 0 \\
\hline Mar. 27...... & 2 & 5 & 1 & $\mathbf{5}$ & 1 & 2 & 2 & 2.5 & 0 \\
\hline Apr. $3 \ldots \ldots \ldots \ldots$ & 0 & 1 & 0 & 0 & 0 & 0 & 0 & 0.1 & $\ldots$ \\
\hline Apr. $6 \ldots \ldots \ldots \ldots$ & 0 & 0 & 0 & 1 & 0 & 1 & 0 & 0.3 & $\ldots$ \\
\hline
\end{tabular}

* The corn border was sprayed once a week beginning February 17, 1951, with 25 per cent parathion wettable powder at 2 pounds of toxicant to 100 gallons.

It can be seen from Figure 2 that the fly population in the melon field outside the corn border never became as low as inside the corn border. Although the owner was spraying the melon field outside the corn border on the average of about four times a week, it is doubtful that this spraying greatly affected the trap catch, for only a very small percentage of the fly population lured to the traps was in the field at any given time. During the last 2 weeks of the experiment it was impossible to spray the field outside the corn border because the field had become too muddy for motorized equipment. However, the fly eatch in this field did not increase despite the fact that it could not be sprayed. This population level, however, was not as low as in the field inside the corn border. During the last month of the experiment the average fly eatch in the melon field outside the corn was 6.4 times as high as in that inside the corn border.

An additional check on the effectiveness of the treatments was made by counting the number of flies that could be seen in 3 minutes at seven stations along the corn border and one in the enclosed melon field. In all, 19 surveys 
were made from February 14 to April 6. The results are shown in Table 7. Note that in the corn border the fly count dropped abruptly from 170.8 per station immediately before spraying to zero 2 days after the first treatment. Thereafter the fly count rose on a number of occasions to as high as 9.5 per station, but these increases were always terminated by subsequent treatments. It can be seen by comparing Tables 6 and 7 that the fly-count method

TABLE 8

TRAP CATCH IN WATERMELON FIELD AT WAIMANALO AFTER VARIOUS TREATMENTS

\begin{tabular}{|c|c|c|c|c|}
\hline Type of application & $\begin{array}{l}\text { Insecticide and lbs. toxi- } \\
\text { cant, to } 100 \text { gals. }\end{array}$ & $\begin{array}{c}\text { Date } \\
\text { treated, } \\
1951\end{array}$ & $\begin{array}{c}\text { Date flies } \\
\text { collected, } \\
1951\end{array}$ & $\begin{array}{l}\text { Flies per } \\
\text { trap-day }\end{array}$ \\
\hline Corn border spray $\ldots \ldots \ldots \ldots \ldots \ldots \ldots \ldots \ldots \ldots \ldots$ & $\begin{array}{l}\text { No treatment......... } \\
\text { DDT, } 2 ; \text { EPN, } 0.27 \ldots \ldots \\
\text { EPN, } 0.27 \ldots \ldots \ldots \ldots \ldots \\
\text { DDT, } 2 ; \text { EPN, } 0.43 \ldots \ldots \\
\text { EPN, } 0.54 \ldots \ldots \ldots \ldots \ldots \\
\text { EPN, } 0.54 \ldots \ldots \ldots \ldots \ldots\end{array}$ & $\begin{array}{l}\text { May } 12 \\
\text { May } 15 \\
\text { May } 19 \\
\text { May } 23 \\
\text { May } 26\end{array}$ & $\begin{array}{l}\text { May } 12 \\
\text { May } 15 \\
\text { May } 19 \\
\text { May } 23 \\
\text { May } 26 \\
\text { May } 30\end{array}$ & $\begin{array}{l}1.1 \\
1.4 \\
0.2 \\
1.4 \\
1.3 \\
0.6\end{array}$ \\
\hline No treatment........ & & ........ & June 2 & 1.7 \\
\hline Air-blown mist on corn and wild vegetation.......... & DDT, 80 ; parathion, 0.5 & June 2 & June 6 & 0.5 \\
\hline No treatment. $\ldots \ldots \ldots \ldots \ldots \ldots \ldots \ldots \ldots \ldots \ldots \ldots \ldots \ldots \ldots \ldots \ldots$ & $\ldots \ldots \ldots \ldots \ldots \ldots$ & $\ldots \ldots \ldots$ & June 9 & 0.3 \\
\hline Conventional spray of corn border and wild vegetation & $\mathrm{EPN}, 0.54 \ldots \ldots \ldots \ldots$ & June 12 & June 15 & 0.4 \\
\hline No treatment. . & & $\begin{array}{l}\ldots \ldots \cdots \\
\ldots \ldots \cdots \\
\ldots \ldots \ldots \\
\ldots \ldots \ldots \\
\ldots \ldots \ldots \\
\ldots \ldots \ldots\end{array}$ & $\begin{array}{l}\text { June } 19 \\
\text { June 25 } \\
\text { June } 30 \\
\text { July } 3 \\
\text { July } 7 \\
\text { July } 10\end{array}$ & $\begin{array}{l}0.2 \\
0.4 \\
1.2 \\
1.5 \\
3.2 \\
8.0\end{array}$ \\
\hline
\end{tabular}

showed a much greater contrast between pretreatment and posttreatment fly populations than was indicated by the trap catch. This difference, like the proportion of male and nongravid females in traps, indicates that the traps lure into the field many flies that would not otherwise be present, and that the trap catch can be considered a conservative estimate of the benefits of the spraying.

As stated previously, melon flies can injure the vines as well as the fruits of cucurbits. A count was made of the number of hills with injured vines and the number of injured vines in 5 locations outside the corn border and 1 in the corn-border plot. Before the first treatment 60 per cent of the hills within the corn border were infested as compared with an average of 25.9 per cent in the remainder of the field. These data indicate that a corn border would have a tendency to increase the infestation in a melon field if it were not treated. The infested vines were removed. Twenty days after the first treatment only 5.7 per cent of the hills in the field within the corn border were infested, as compared with an average of 17.8 per cent in the remainder of the field. In the above locations the reduction in the per cent of injured hills was, respectively, 90.5 and 31.3 per cent. 
Experiment with Watermelons at Waimanalo. A 3-acre privately owned field in Waimanalo was planted to watermelons and a double-row corn border was planted completely around it. Two weeks after beginning of treatment, one of the rows of corn was removed. The north side of the field was bordered by a papaya orchard and the remainder by natural vegetation containing a number of plants upon which the melon fly is frequently found, such as cocklebur, X Xathium saccaratum; spiny amaranth, Amaranthus spinosus; castor bean, Ricinus communis; and Solanum nigrum, as well as volunteer kafir corn and sugar cane. Eight traps, 4 set in the corn border and 4 in the melon field, were operated throughout the period of study with the exception of 3 days, June 9 to 12 .

Beginning May 12, 1951, the corn border was sprayed semiweekly through May 26. The insecticides and dosages are shown in Table 8, along with those of treatments of the corn border plus the adjacent wild vegetation, which will be discussed later. Separate counts were made of gravid females, nongravid females, and males, but these are combined in Table 8 in order to simplify the table and avoid confusion in the evaluation of the treatments. The trap catches were relatively low throughout the period of the experiment, and probably the minor variations cannot be attributed to the treatments even though in the previous experiments it was shown that appreciable reductions in fly abundance were obtained. The fly population would be expected to increase during the course of the experiment if no treatment had been applied. The corn-border spraying may have prevented an increase in the fly population that would have resulted in serious damage to the crop.

On May 23, 20 vines were examined in each of four areas of the field and none were injured by the melon fly. On June 6, 15 melons 4 inches or less in length were examined in each of four areas in the field and 6.7 per cent were found to have oviposition punctures. If flies had been abundant many of the vines and the majority of exposed fruits of this size would have been infested.

\section{TREATMENT OF CORN BORDER AND SURROUNDING WILD VEGETATION}

In the course of the above experiment, it was observed that numbers of flies were resting on castor bean, cocklebur, Solanum, and volunteer kafir corn growing in the area adjacent to the watermelon field rather than on the treated corn border. Therefore it was surmised that the treatment of these plants would further increase the effectiveness of the control program in the watermelon field.

Treatment with Mist Spray. On June 2 the corn border and adjacent vegetation on all sides of the watermelon field at Waimanalo were treated by means of the Lawrence mist blower previously described. About 25 gallons of spray mixture was used per treatment. This consisted of 20 gallons of water, 5 gallons of technical xylene, 0.5 gallon of light medium emulsive spray oil, 20 pounds of technical DDT, and 2 pounds of 25 per cent parathion wettable powder. One ounce of Triton B-1956 was used as the emulsifier. The DDT was dissolved in the xylene before the latter was poured into the spray tank. The parathion wettable powder was merely allowed to sift into 
the mixture. In treating, 3 complete trips were made around the field. On the first one the air-blown mist was directed against the corn border, on the second it was directed toward the strip of vegetation immediately beyond the corn border, and on the third the mist was directed so as to travel the maximum distance from the melon field.

Although the work was begun before sunrise, there was some wind. Consequently on the leeward side of the field the air-blown mist traveled for hundreds of feet, but on the windward sides the mist probably did not travel more than 20 to 30 feet beyond the machine. It was estimated that an area
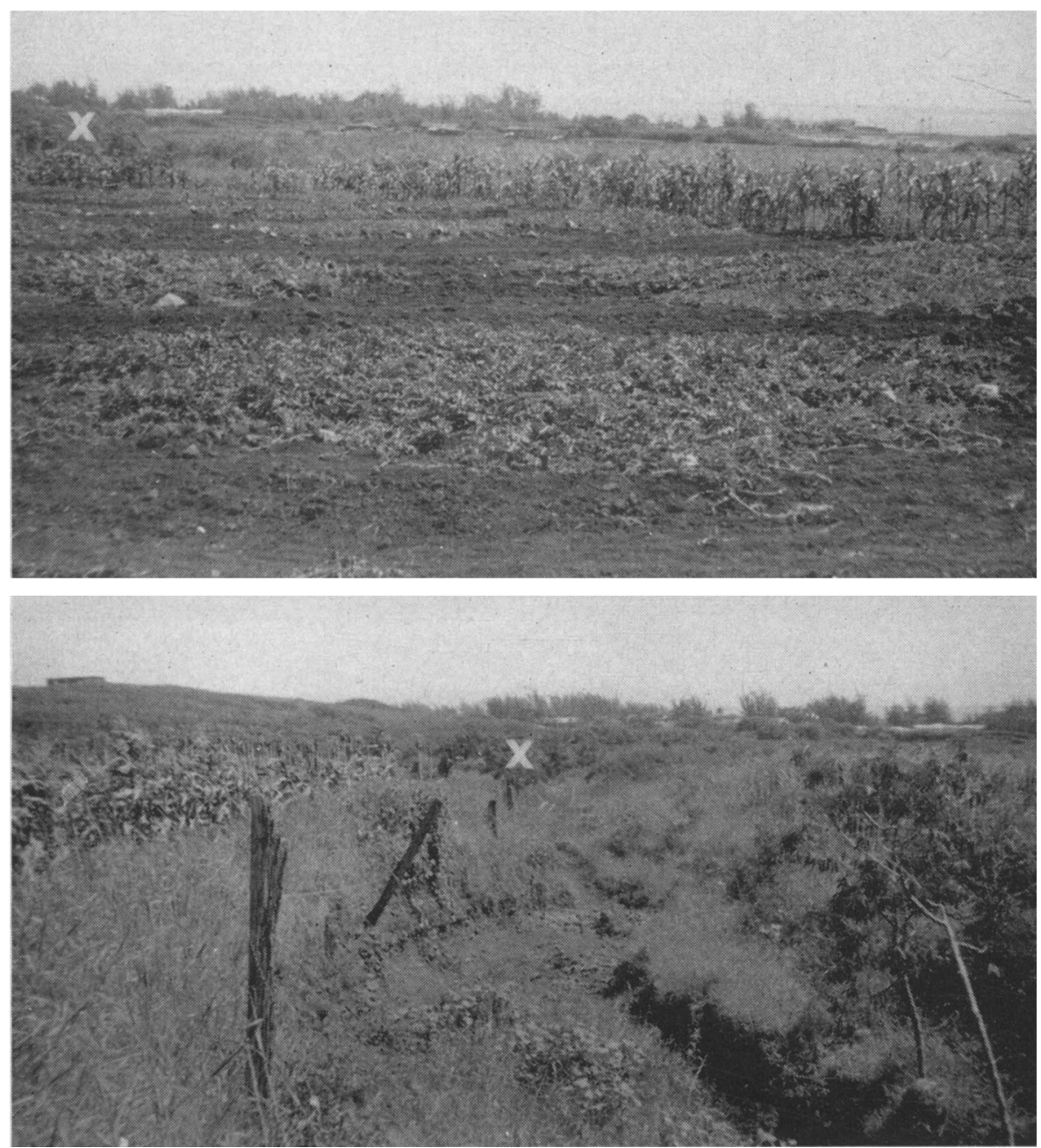

Fig. 3. The corn-bordered watermelon field in Waimanalo. Above: The melon vines with the single row of corn along the east side of the field. Below : the corn border (left) and an adjacent gulch that harbored many melon flies, particularly in the clump of castor beans marked by the " $X$ " in both photographs. These flies were eliminated either with a mist blower or with the conventional spray rig used to spray the corn. 
of at least 3 acres surrounding the melon field was effectively reached by the air-blown mist.

On the leeward side of the melon field, 8 small screen cages containing 25 flies each were placed in the corn border ( 2 cages) and at various distances from the corn border ranging from 3 to 180 feet. An hour after treatment these were examined and it was found that in every cage all the flies had already been paralyzed and were lying in a moribund condition on the bottom of the cage. Therefore, it was obvious that at least as a "space spray" the air-blown mist had been highly effective over a large area surrounding the corn field, particularly on the leeward side of the field. The residual effect from this highly concentrated insecticidal mist was also investigated and is reported in a later section.

Treatment with Conventional Spray. On June 12 the corn border and surrounding vegetation were again treated, but this time with the conventional spray equipment. It was possible to spray the wild vegetation beyond the corn to a distance of about 20 feet on the windward side of the corn border, although in a few instances where host plants occurred at a still greater distance, the spray hose was pulled out beyond the corn border to enable the spraying of these plants. An example of such an area is shown in Figure 3. The clump of castor bean plants indicated by the " $\mathrm{X}$ " in Figure 3 harbored many flies, but could be reached only by pulling the hose some distance from the corn border. The treatment of the host plants eliminated the flies present on the plants at the time of spraying, and residues left by the spray continued to deplete the fly population that normally would be resting in the infested gulch. This resulted in a greater reduction of flies in the near-by watermelon field than would be effected by the spraying of the corn border alone.

The results of the combined treatment of the corn border and the adjacent wild vegetation are included in Table 8 , along with those of the previous treatments of the corn border only. As soon as the surrounding vegetation was treated, in addition to the corn border, the trap catches were reduced and remained uniformly low until the last week in June. The potentialities for injury to the watermelon field used in the present experiment are shown by the rapid rise in the fly catches in the invaginated glass traps beginning about 2 weeks after the last complete treatment on June 12.

\section{LABORATORY CAGE TESTS OF RESIDUES WEATHERING IN THE FIELD}

Laboratory tests to determine the weathering of the insecticidal residues were carried out in conjunction with many of the field experiments discussed and in a few special weathering tests. The sprayed foliage and fruits were brought into the laboratory at various periods after treatment, and flies were confined in small eages with them, usually for a 24 -hour period. In one test, sections of cucumbers were placed in the cages. With corn a 7 -inch section of the leaf was bent in half and placed in the test cage so that the two ends were at the bottom and the folded portion at the top of the cage. The upper surface of the leaf was on top, and the flies spent the greater part of the time on the 
under surface as in the field. For each treatment, leaf sections were placed in 3 cages and 25 flies were placed in each cage. More time was spent by the flies on the cage, particularly the ceiling, than on the foliage, yet observations and the results obtained showed that they spent a part of their time walking or resting on the latter.

TABLE 9

MORTALITY OF MELON FLIES CONFINED WITH FRUIT OR FOLIAGE FROM TOMATO FIELD AND CORN BORDER AT POAMOHO*

\begin{tabular}{|c|c|c|c|c|c|}
\hline \multirow{2}{*}{$\begin{array}{c}\text { Date } \\
\text { sprayed } \\
(1950)\end{array}$} & \multirow{2}{*}{$\begin{array}{l}\text { Insecticide and lbs. toxicant } \\
\text { to } 100 \text { gals. }\end{array}$} & \multirow{2}{*}{ Host } & \multirow{2}{*}{$\begin{array}{l}\text { Hours } \\
\text { flies } \\
\text { confined } \\
\text { on } \\
\text { host }\end{array}$} & \multicolumn{2}{|c|}{$\begin{array}{l}\text { Mortality after res- } \\
\text { idues had weathered }\end{array}$} \\
\hline & & & & 6 hours & 10 days \\
\hline Oct. 2 & $\begin{array}{l}\text { Parathion, } 0.5 \ldots \ldots \ldots \ldots \ldots . \\
\text { Dieldrin, } 1.0 \ldots \ldots \ldots \ldots \ldots \ldots\end{array}$ & 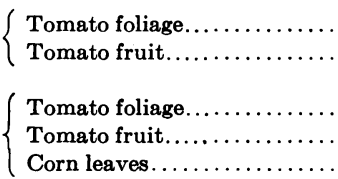 & $\begin{array}{l}24 \\
24 \\
\\
24 \\
24 \\
24\end{array}$ & $\begin{array}{r}40 \\
97 \\
\\
64 \\
44 \\
100\end{array}$ & $\begin{array}{r}\cdots \\
\cdots \\
68 \\
92 \\
100\end{array}$ \\
\hline Oct. 12 & EPN, $1.0 \ldots \ldots \ldots$ & 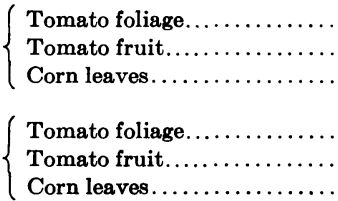 & $\begin{array}{l}13 \\
13 \\
13 \\
\\
13 \\
13 \\
13\end{array}$ & $\begin{array}{l}100 \\
100 \\
100 \\
\\
100 \\
100 \\
100\end{array}$ & $\begin{array}{l}\cdots \\
\cdots \\
\cdots \\
\cdots \\
\cdots \\
\cdots\end{array}$ \\
\hline
\end{tabular}

* A tomato field and a few near-by cornstalks were sprayed with a power sprayer on October 2 and October 12 , 1950 , and foliage and fruit were placed in laboratory test cages with melon flies 6 hours and, with those sprayed with dieldrin, again 10 days after treatment. Flies were counted after they had been confined with the residues for 24 hours or, with the Oct. 12 spraying, 13 hours.

Cucumbers from Mid-Pacific. A week after treating the cucumber vines on October 3, 1950 (see p. 566), cucumbers from the treated plots were brought into the laboratory, cut in the middle, and stood up on their cut ends in screen cages so that the melon flies put into the cages could crawl over them. Three cages were prepared in this manner for each plot. The flies were confined with the cucumbers for 24 hours. There was no evidence of any insecticidal residue on these cucumbers. Even if the low dosages used would retain their effectiveness for a week, the rapid growth of the cucumbers would present a preponderance of unprotected surface to the flies. Marketable cucumbers were picked just before treatment and the smallest fruits can attain marketable size in one week.

Tomatoes and Corn from Poamoho. After spraying the Poamoho tomato field on October 2 (see p. 567), tomato foliage and fruit and also leaves from sprayed corn plants were taken to the laboratory and placed in eages with 25 melon flies for a 24 -hour period. Plants sprayed with dieldrin were again tested 10 days later, together with plants sprayed with EPN or parathion on October 12.

The results are shown in Table 9. With dieldrin, there was higher mortality of the flies confined in the cages with corn foliage than in the cages 
with tomatoes. Ten-day-old dieldrin residues on corn leaves, from the October 2 spraying, gave 100 per cent kill in a 24 -hour period; on tomato foliage and fruit they gave less than 100 per cent kill, but the kill averaged higher than on the day the spray was applied. There was 100 per cent mortality of the flies confined for 13 hours with all types of foliage and fruit that had been sprayed 6 hours before with EPN or parathion at 1 pound of actual toxicant to 100 gallons.

Tomato Field at Waimanalo. Laboratory cage tests were made with foliage from the corn border around the Waimanalo tomato field after the dieldrin spraying of November 20, 1950 (see p. 574). Flies confined for 24 hours on either the upper or under sides of leaves gathered 4 days after treatment suffered 100 per cent mortality, despite the fact that much rain fell in the intervening period.

Watermelon Field at Waimanalo. Laboratory cage tests were made in conjunction with the spraying of the border and wild vegetation around the watermelon field at Waimanalo. Corn leaves were gathered on June 2 before the air-blown mist was applied so that a test could be made of the effectiveness of the EPN residues of the spray applied with a conventional power sprayer on May 26. It was found that these residues still gave a 100 per cent kill when confined with melon flies for 24 hours.

Immediately after the mist-blower treatment, corn leaves that had developed since the conventional border spray of the previous week, and containing only the residue from the mist blower, were gathered. In addition, leaf samples were obtained from cocklebur at 20 and 50 feet, and kafir corn at 75 and 100 feet, from the melon field on the lee side. Leaves or leaf sections from each of these locations were placed in each of 3 cages, along with 25 melon flies.

The results of the tests were as follows:

\begin{tabular}{lcc}
\multicolumn{1}{c}{ Foliage } & $\begin{array}{c}\text { Distance from } \\
\text { melon field, feet }\end{array}$ & $\begin{array}{c}\text { Average per cent } \\
\text { mortality from residue }\end{array}$ \\
New growth of corn & In corn border & 100 \\
Cocklebur & 20 & 99 \\
Cocklebur & 50 & 95 \\
Kafir corn & 75 & 100 \\
Kafir corn & 100 & 100
\end{tabular}

It appeared from the laboratory cage tests that the residues left by the mist were highly effective at least up to 100 feet from the corn field on the lee side of the field. The residues on kafir-corn leaves appeared to be more effective than those from cocklebur leaves, but the difference was probably due to the difference in the frequency and duration of contact of the flies with the residues. The cocklebur leaves were placed on the bottoms of the cages and it is known that only a small percentage of the flies rest on the bottom of a cage at any given moment. Nevertheless, they all probably eventually make a limited contact with the foliage as they move about the cage.

Three days after the air-blown mist was applied, foliage was again collected from the locations indicated above and used in laboratory cage tests. The corn leaves in the corn border and having residue only from the airblown mist gave a 63 per cent kill. The residue on foliage from all the other locations listed above was completely ineffective. 
Special Weathering Experiments at Mid-Pacific. During April and May, 1951, a series of residue weathering experiments were made in the MidPacific area. On April 7, cornstalks were sprayed with DDT at 2 and 4 pounds of toxicant to 100 gallons, methoxychlor at 2 pounds, and parathion at 0.5 pound. The per.cent kills from leaf sections confined with flies one day after treatment were, respectively $83,100,87$, and 100 (Table 10 , first section) and on the second day they averaged practically the same. On the third day there was 0.52 inch of rain. The average reduction in per cent kill for DDT and methoxychlor was 26.0 per cent, while for parathion it was 84 per cent.

Then on April 13, DDT, dieldrin, and parathion wettable powders were applied to corn foliage. Leaf sections were placed in the cages as soon as the spray residue had dried, then again in 2 days, 4 days, and 6 days. The results after the flies were exposed to the residues for the usual 24-hour period are shown in the second section of Table 10. One hundred per cent kills were obtained with DDT at 4 pounds of actual toxicant to 100 gallons, dieldrin at 0.5 pound, and parathion at 0.12 and 0.25 pound. None of the treatments gave less than 82 per cent kill. Two days later the average per cent kill for all 3 insecticides at all dosages had dropped only 3.6 per cent and in 4 days only 8.2 per cent. There was 0.15 inch of rain on the fifth day of the experiment, which decreased the effectiveness of the parathion much more than that of DDT or dieldrin. The effectiveness of parathion dropped about 90 per cent as compared with that of the fourth day, while the average effectiveness of the other insecticides dropped only 35 per cent. This is to be expected in view of the relatively high water solubility of parathion as compared with that of the other insecticides.

Again on April 21 various insecticides as wettable powders were applied to corn foliage. The object of this experiment was to use the approximate minimum concentration necessary to give 100 per cent kill immediately after application and then determine the rates of decrease in effectiveness of the different insecticides. The third section of Table 10 shows the rate of decrease in the effectiveness of 9 insecticide residues on corn leaves, some at two concentrations of insecticide. All treatments resulted in a 100 per cent kill when flies were confined with the leaf sections in the test cages 1 hour after application of the sprays. A rain of 0.16 inch fell 1 day after treatment, and that was the heaviest rain throughout the period of the experiment.

After 2 days of weathering the majority of the treatments no longer resulted in 100 per cent kill, but the decline in effectiveness of the majority of the insecticides was very small from the second to the sixth day or even to the eleventh day. Parathion and chlordane declined most rapidly in effectiveness and were the only insecticides that resulted in less than 50 per cent kill 6 days after treatment.

All insecticides but parathion and chlordane declined very slowly in their residual effectiveness during an 11-day period when there were occasional showers, but never any heavy rainstorm. Leaving out parathion, chlordane, and also dilan, which further work showed was used at too high a concentration, the average per cent decline in the insecticidal effectiveness of the insecticides listed in the third section of Table 10 in comparison with the 
TABLE 10

\section{MORTALITY OF MELON FLIES CONFINED WITH CORN LEAVES FROM THE RESIDUE EXPERIMENTT AT MID-PACIFIC*}

\begin{tabular}{|c|c|c|c|c|c|c|c|c|c|}
\hline \multirow{2}{*}{$\begin{array}{c}\text { Date } \\
\text { sprayed } \\
(1951)\end{array}$} & \multirow{2}{*}{$\begin{array}{l}\text { Insecticide and lbs. } \\
\text { toxicant } \\
\text { to } 100 \text { gals. }\end{array}$} & \multicolumn{8}{|c|}{ Per cent mortality after residues had weathered: $\dagger$} \\
\hline & & $1 \mathrm{hr}$. & 1 day & 2 days & 3 days & 4 days & 6 days & 8 days & $\begin{array}{c}10 \text { or } 11 \\
\text { days } \ddagger\end{array}$ \\
\hline \multirow{4}{*}{ Apr. 7} & DDT, $2.0 \ldots \ldots \ldots$ & $\ldots$ & 83 & 79 & 52 & $\ldots$ & $\ldots$ & $\ldots$ & $\ldots$ \\
\hline & DDT, $4.0 \ldots \ldots \ldots$ & $\ldots$ & 100 & 100 & 93 & $\ldots$ & $\ldots$ & $\ldots$ & $\ldots$ \\
\hline & Methoxychlor, 2.0 . & $\ldots$ & 87 & 92 & 53 & $\ldots$ & $\ldots$ & $\ldots$ & $\ldots$ \\
\hline & Parathion, $0.5 \ldots \ldots \ldots$ & $\ldots$ & 100 & 100 & 16 & $\ldots$ & $\ldots$ & $\ldots$ & $\ldots$ \\
\hline \multirow{7}{*}{ Apr. 13} & $\mathrm{DDT}, 1.0 \ldots \ldots \ldots \ldots$ & 86 & $\ldots$ & 77 & $\ldots$ & 84 & 51 & $\ldots$ & $\ldots$ \\
\hline & DDT, $2.0 \ldots \ldots \ldots$ & 92 & $\ldots$ & 92 & $\ldots$ & 88 & 64 & $\ldots$ & $\ldots$ \\
\hline & DDT, $4.0 \ldots$ & 100 & $\ldots$ & 96 & $\ldots$ & 96 & 84 & $\ldots$ & $\ldots$ \\
\hline & Dieldrin, $0.25 \ldots$ & 82 & $\ldots$ & 85 & $\ldots$ & 69 & 26 & $\ldots$ & $\ldots$ \\
\hline & Dieldrin, $0.50 \ldots$ & 100 & $\ldots$ & 91 & $\ldots$ & 97 & 57 & $\ldots$ & $\ldots$ \\
\hline & Parathion, 0.12 . & 100 & $\ldots$ & 85 & $\ldots$ & 80 & 8 & $\ldots$ & $\ldots$ \\
\hline & Parathion, $0.25 \ldots$ & 100 & $\ldots$ & 100 & .. & 92 & 9 & $\ldots$ & $\ldots$ \\
\hline \multirow{15}{*}{ Apr. 21} & Parathion, 0.125. . & 100 & $\ldots$ & 48 & $\ldots$ & 41 & 19 & $\ldots$ & $\ldots$ \\
\hline & Parathion, $0.25 \ldots$ & 100 & $\cdots$ & 63 & $\ldots$ & 65 & 37 & $\ldots$ & 9 \\
\hline & $\mathrm{EPN}, 0.135 \ldots \ldots$ & 100 & $\ldots$ & 88 & $\ldots$ & 97 & 79 & $\ldots$ & 27 \\
\hline & $\mathrm{EPN}, 0.27 \ldots \ldots \ldots$ & 100 & $\ldots$ & 92 & $\ldots$ & 91 & 93 & $\ldots$ & 95 \\
\hline & DDT, $2.0 \ldots \ldots \ldots$ & 100 & $\cdots$ & 76 & $\cdots$ & 59 & 97 & $\cdots$ & 61 \\
\hline & $\mathrm{DDT}, 4.0 \ldots \ldots \ldots \ldots$ & 100 & $\cdots$ & 81 & $\ldots$ & 95 & 100 & $\cdots$ & 100 \\
\hline & DDT, $2.0 ; \mathrm{EPN}, 0.27 \ldots$ & 100 & $\ldots$ & 100 & $\ldots$ & 100 & 100 & $\ldots$ & 100 \\
\hline & Methoxychlor, $2.0 \ldots$ & 100 & $\ldots$ & 72 & $\ldots$ & 69 & 54 & $\ldots$ & 89 \\
\hline & Methoxychlor, 4.0. & 100 & $\cdots$ & 81 & $\cdots$ & 79 & 79 & $\ldots$ & 52 \\
\hline & Dieldrin, $1.0 \ldots \ldots$ & 100 & $\ldots$ & 100 & $\ldots$ & 96 & 99 & $\ldots$ & 72 \\
\hline & Dieldrin, $2.0 \ldots \ldots$ & 100 & $\ldots$ & 99 & $\ldots$ & 97 & 100 & $\ldots$ & 100 \\
\hline & Aldrin, $1.0 \ldots \ldots$ & 100 & $\ldots$ & 99 & $\ldots$ & 68 & 89 & $\ldots$ & 92 \\
\hline & Toxaphene, 1.6. & 100 & $\ldots$ & 85 & $\ldots$ & 95 & 97 & $\ldots$ & 85 \\
\hline & Chlordane, $2.0 \ldots$ & 100 & $\ldots$ & 75 & $\ldots$ & 59 & 33 & $\ldots$ & 13 \\
\hline & Dilan, $4.0 \ldots \ldots \ldots \ldots \ldots$ & 100 & $\ldots$ & 100 & $\ldots$ & 100 & 100 & $\ldots$ & 100 \\
\hline \multirow{11}{*}{ May 3} & Parathion, 0.25. . & $\ldots$ & 100 & 29 & $\ldots$ & 28 & $\ldots$ & 21 & 7 \\
\hline & $\mathrm{EPN}, 0.27 \ldots \ldots$ & $\cdots$ & 100 & 92 & $\cdots$ & 57 & $\ldots$ & 49 & 61 \\
\hline & $\mathrm{DDT}, 2.0 \ldots \ldots \ldots \ldots$ & $\ldots$ & 93 & 73 & $\ldots$ & 65 & $\ldots$ & 55 & 29 \\
\hline & DDT, $2.0+$ adjuvant. & $\cdots$ & 99 & 75 & $\cdots$ & 88 & $\cdots$ & 24 & 23 \\
\hline & DDT, $4.0 \ldots \ldots \ldots \ldots$ & $\cdots$ & 93 & 92 & $\ldots$ & 95 & $\ldots$ & 67 & 36 \\
\hline & DDT, 2.0 ; parathion, 0.25 & $\cdots$ & 100 & 100 & $\cdots$ & 92 & $\cdots$ & 61 & 34 \\
\hline & Dieldrin, $1.0 \ldots \ldots \ldots \ldots$ & $\ldots$ & 100 & 100 & $\cdots$ & 100 & $\cdots$ & 73 & 51 \\
\hline & Toxaphene, $1.6 \ldots \ldots \ldots$ & $\ldots$ & 100 & 88 & $\ldots$ & 65 & $\ldots$ & 32 & 28 \\
\hline & Dilan, 1.0 + adjuvant. & $\ldots$ & 100 & 92 & $\ldots$ & 97 & $\ldots$ & 65 & 85 \\
\hline & Dilan, 2.0 + adjuvant $\{$. & $\ldots$ & 100 & 100 & $\cdots$ & 96 & $\ldots$ & 83 & 59 \\
\hline & Dilan, $2.0 \| \ldots \ldots \ldots \ldots$ & $\ldots$ & 100 & 97 & $\ldots$ & 97 & $\ldots$ & 87 & 85 \\
\hline
\end{tabular}

* The corn was sprayed with a power sprayer. All insecticides were used as wettable powders. The melon flies were confined with the sprayed corn leaves for 24 hours before counts were made.

$t$ The only rains of importance during the course of these experiments were as follows: 0.52 in. on April 10 before the tests made on the third day after the April 7 spraying; 0.15 in. on April 18, the fifth day after the April 13 spraying; 0.16 in. April 22, the day after the April 21 spraying; and a number of showers after the April 21 and May 3 sprayings, the heaviest, 0.12 in., on May 8.

$\ddagger 10$ days for May 3 spraying, 11 days for April 21 spraying.

White flour was added at the rate of $1 \mathrm{lb}$. to 100 gals.

Santomerse (wetting agent) was added at the rate of 1 weight per cent to a 50 per cent dilan dust concentrate to make a wettable powder.

|| A 50 per cent dilan dust concentrate was used without adjuvant. 
effectiveness of the freshly deposited residues, was as follows: in 2 days, 11.5 ; 4 days, 14.0 ; 6 days, 10.3 ; and 11 days, 20.6. The implication of these data is that if the corn border were sprayed with such insecticides twice a week, or even once a week, there would be a gradual accumulative action of the residues provided there was no rain.

Table 10 (third section) shows that EPN, although known to be less toxic initially than parathion, may still be used at very low concentrations. The lowest concentration listed is 0.135 pound of actual toxicant per 100 gallons, and it is not known how low a concentration might be used to give an initial kill of 100 per cent on corn. In addition, EPN has a much more prolonged residual action than parathion. A concentration of 0.135 pound of actual EPN to 100 gallons ( 0.5 pound of 27 per cent EPN wettable powder) was much superior to 0.25 pound of actual parathion (1 pound of 25 per cent wettable powder). Yet the 0.5 pound of EPN wettable powder would be less expensive than the 1 pound of wettable parathion.

Table 10 (third section) shows also the result of adding 0.27 pound of actual EPN and 2 pounds of actual DDT to 100 gallons of water. A 100 per cent kill was obtained in every test over the 11-day period.

The fourth section of Table 10 shows the results of an experiment similar to the preceding but with fewer insecticides. Dilan was used at lower concentrations. Its toxicity relative to other insecticides in laboratory experiments had not indicated that it could be used in concentrations as low as those shown here, but its high depositing ability and resistance to weathering enhanced its relative effectiveness in the field. It can be seen that 1 pound of actual dilan to 100 gallons appears to be about as effective as 1 pound of dieldrin or 4 pounds of DDT. In this experiment, however, the dilan was no more effective at 2 pounds to 100 gallons than at 1 pound.

Note that the addition of white flour as a "sticker," at the rate of 1 pound to 100 gallons, contributed nothing to the residual effectiveness of the DDT spray.

Leaving out parathion, the rate of decline of which is out of line with the other insecticides, the average per cent reduction in residual effectiveness of the insecticides listed in the fourth section of Table 10, as compared with the effectiveness of the day-old deposits, was as follows: 1 day, 7.7 ; 3 days, 13.5; 7 days, 39.5 ; and 9 days, 50.1 .

\section{CONCLUSIONS}

The habit of melon flies of leaving the crop field in the late afternoon and resting on surrounding vegetation during the night has led to control measures that have proved to be far superior to treatment of the crop plants (Nishida and Bess, 1950).

The present experiments have dealt primarily with the spraying of corn planted around the border of the crop fields. Many flies are attracted to the corn borders, on which they can be killed either by space sprays or by their contact with the spray residues left on the corn. Advantages of border spraying are not only its greater effectiveness and reduced expense, but also the avoidance of poisonous residues on the protected crop.

For the control of melon flies, EPN, parathion, dieldrin, and DDT appear 
to show the most promise. Suggested concentrations of actual toxicant for conventional spraying of a corn border, in pounds per 100 gallons, are as follows: EPN, 0.27 ; $^{i}$ parathion, 0.25 ; dieldrin, 1.0 ; and DDT, 2. Both upper and lower surfaces of the leaves should be sprayed. Laboratory cage tests of sprayed foliage and fruit obtained from the field showed that the effectiveness of parathion was more adversely affected by rain than that of the other insecticides mentioned.

In addition to the corn border, when attractive vegetation surrounds the crop field it should be sprayed as far back as the spray stream will carry. Concentrated sprays may be applied by means of a mist blower at night or during the early morning hours. By this method the insecticide can be rapidly and inexpensively distributed over a wide area surrounding the crop field. It would appear that a corn border may be unnecessary when there is attractive vegetation surrounding the field. Good control has been obtained by treating only the bordering vegetation (Nishida and Bess, 1950).

The larger the crop field the greater the effectiveness of a treatment applied to a corn border or other bordering vegetation, since the melon-fly density usually decreases with increase in the distance from the border of the field. In addition, for a given number of flies escaping treatment, the per cent of damage is reduced as the size of the field and the number of fruits subject to infestation are increased.

Because of the distances the melon fly travels, it could be most successfully combated if it were considered as a community problem. In certain areas in Hawaii where the flies are not abundant, but are present in sufficient numbers to result in crop losses if not controlled, treatments have in some instances been successful with spray programs that would probably fail in other areas where the flies are more numerous. In the latter areas, if every grower would adopt a control program known to be effective in substantially reducing the number of flies, the community-wide effect of such a program would result in a great reduction in the fly population, with a corresponding increase in the chances of successful control for any individual grower. A community-wide crop-sanitation program would also be an important step in this direction.

\section{SUMMARY}

Two experiments made early in the course of the present investigations demonstrated the futility of attempting to control melon flies by treating the crop field. The gravid flies enter the field only to oviposit and apparently do not spend sufficient time on the crop to be killed by the residues. As space sprays the treatments are likewise not effective because only a small percentage of the flies are in the field at any time of the day that the treatment might be applied.

In contrast, results with experiments on spraying of corn borders or border vegetation were promising.

In a cucumber patch on the University of Hawaii campus in which the corn border was sprayed weekly, the percentage of uninfested cucumbers was increased from less than 1 before treatment to 53 one week after the first treat-

${ }^{6} \mathrm{EPN}$ is formulated as a 27 per cent wettable powder. One pound to 100 gallons of water would result in 0.27 pound of actual toxicant. 
ment and 67 one week after the second treatment. Before treatment only 24 per cent of the fruit had less than 6 oviposition marks ("stings"), but after the first spray this percentage increased to 89 and after the second spray further increased to over 98 .

In a tomato field on the University of Hawaii campus in which the pretreatment trap catch in invaginated glass traps was 35 melon flies per trapday, the fly catch was reduced to nil after the first weekly treatment of the corn border and continued at a subeconomic level for the 6-week duration of the experiment. Although practically all ripe tomatoes were infested at the beginning of the experiment, no infested tomatoes could be found out of 200 fruits examined at random 3 weeks after the date of the first treatment.

At the University of Hawaii Agricultural Experiment Farm at Waimanalo a small tomato field 50 by 400 feet in area had a row of corn planted along about two thirds of its border. The corn was sprayed weekly with parathion, dieldrin, or methoxychlor sprays. Over the 25-day period of the experiment the fly catch decreased from 11 to 5 per trap-day. This reduction was not sufficient to prevent serious damage to the tomatoes in this small field. In a subsequent experiment with various cucurbits planted in the same field, parathion, dieldrin, or DDT was applied to a double-row corn border which completely surrounded the field. The insecticides were applied twice a week, but at reduced concentrations. In a 2-month period the fly catch decreased from 7 to 0.2 per trap-day.

In a 3-acre watermelon field near Waianae a double row of corn was planted around about a $1 / 2$-acre of the east end of the field. The corn border was sprayed once a week with parathion wettable powder and the results were compared with those obtained in the remainder of the field, in which the melon vines were sprayed four times a week. During the last month of the 7-week experiment the fly catch was over six times as high in the melon field without a corn border as in the adjoining field with a corn border. The fly catch increased sharply after each rain, possibly because of the removal of the parathion residues, but was again reduced to low levels by the next spray.

After the treatments there was a 90 per cent reduction in the number of infested vines in the corn-bordered field as compared to a 31 per cent reduction in the adjoining field without a corn border.

In a 3-acre watermelon field at Waimanalo a double row of corn was planted completely around the field, and one of the rows was removed in 3 weeks. The corn was sprayed twice a week with either EPN or a combination of EPN and DDT. The fly population was apparently held at subeconomic levels by the corn-border spraying. Subsequently, the fly catch was further reduced by spraying the surrounding wild vegetation as well as the corn, or by treating both by means of a mist blower. In this field, 60 melons 4 inches or less in length were examined and only 6.7 per cent had oviposition punctures.

Laboratory cage tests of sprayed foliage and fruit obtained from field experiments showed that the effectiveness of parathion was more adversely affected by rain than that of any other insecticide used in the experiments. The average per cent reduction in the insecticidal effectiveness of residues of DDT, methoxychlor, dieldrin, aldrin, toxaphene, and EPN in the field on corn foliage as compared with the effectiveness of these residues immediately after 
treatment, in one experiment was as follows: in 2 days, $11.5 ; 4$ days, $14.0 ; 6$ days, 10.3 ; and 11 days, 20.6. In another experiment the average per cent reduction in the insecticidal effectiveness of the residue of DDT, dieldrin, toxaphene, and EPN, as compared with the effectiveness of these residues one day after treatment, was as follows: in 1 day, 7.7 ; 3 days, 13.5 ; 7 days, 39.5; and 9 days, 50.1 .

\section{ACKNOWLEDGMENTS}

Through a coöperative arrangement with the Department of Vegetable Crops of the University of Hawaii, 2 acres of land close to the University was planted and cared for by this Department so as to provide test plots during the course of the project described in this paper. In addition, corn was planted around a crop field at the University's Experimental Field Station at Waimanalo for use in the melon fly research program. The writers wish to express their appreciation for this coöperation.

The writers had the help of Mr. Clarence Nihei as a laboratory and field assistant. They are also indebted to Mr. Charles Sugimoto, in Lualualei Valley, and Mr. A. H. Fukunaga at Waimanalo for the use of their melon fields for experimental tests and for aid in other ways. Dr. M. M. Barnes and Dr. A. E. Michelbacher of the University of California read the manuscript and offered valuable criticism.

A number of insecticide companies generously donated large quantities of insecticides for the melon-fly experiments. These companies, and insecticides donated, are as follows: American Cyanamid Company (parathion), California Spray Chemical Corporation (DDT, parathion), E. I. du Pont de Nemours and Company (EPN, methoxychlor), Julius Hyman and Company (dieldrin, aldrin), Niagara Chemical Division of Food Machinery and Chemical Corporation (parathion, DDT, methoxychlor, lindane, chlordane), and Velsicol Corporation (chlordane, heptachlor). 


\section{LITERATURE CITED}

BaCk, E. A., and C. E. Pemberton

1917. The melon fly in Hawaii. U. S. Dept. Agr. Dept. Bul. 491: 1-64.

Brown, A. W. A.

1951. Insect control by chemicals. vii +817 p. 98 figs. John Wiley \& Sons., Inc., New York, N.Y.

Ebeling, W.

1953a. Laboratory experiments on the control of three species of fruit flies (Tephritidae). Hilgardia 21: 515-72.

1953b. Physical factors in the deposition and persistence of solids and liquids in both liquid and gaseous systems. Amer. Chem. Soc., Adv. in Chem. Ser. (In press.)

Holdaway, F. G.

1945. Research on DDT for the control of agricultural insects in Hawaii. Hawaii Ent. Soc. Proc. 12: 301-3.

Holdaway, F. G., O. C. McBride, Y. Tanada, and T. Nishida

1947. Progress in the control of melon fly. Hawaii Agr. Exp. Sta. Rept. 1944-46: 61-64. MARSH, H. O.

1910. Report of the Assistant Entomologist. Hawaii Bd. Agr. and Forestry Rept. 1910: $152-59$.

McPhaIL, M.

1943. Linseed oil soap-a new lure for the melon fly. Jour. Econ. Ent. 36: 426-29.

NishidA, T., and H. A. Bess

1950. Applied ecology in melon fly control. Jour. Econ. Ent. 43: 877-83.

Severin, H. H. P., H. C. Severin, and W. J. Hartung

1914. The ravages, life history, weights of stages, natural enemies and methods of control of the melon fly (Dacus cucurbitae Coq.). Ent. Soc. Amer. Ann. 7: 177-207. 
The journal Hilgardia is published at irregular intervals, in volumes of about 600 pages. The number of issues per volume varies.

Subscriptions are not sold. The periodical is sent as published only to libraries, or to institutions in foreign countries having publications to offer in exchange.

You may obtain a single copy of any issue free, as long as the supply lasts; please request by volume and issue number from:

\section{Publications Office \\ College of Agriculture \\ Berkeley 4, California}

The limit to nonresidents of California is 10 separate issues on a single order. A list of the issues still available will be sent on request.

In order that the information in our publications may be more intelligible, it is sometimes necessary to use trade names of products or equipment rather than complicated descriptive or chemical identifications. In so doing, it is unavoidable in some cases that similar products which are on the market under other trade names may not be cited. No endorsement of named products is intended nor is criticism implied of similar products which are not mentioned. 


\section{CONTENTS}

Laboratory Experiments on the Control of Three

Species of Fruit Flies (Tephritidae)

Introduction . . . . . . . . . . . . . . . 515

Equipment, Technique, and Materials Tested . . . . . . 516

Factors That May Cause Variation in the Results . . . . . 524

Experiments with the Settling Tower . . . . . . . . 531

Experiments with Sprays . . . . . . . . . . . . . 547

Summary . . . . . . . . . . . . . . . . 559

Acknowledgments . . . . . . . . . . . . . . 561

Literature Cited . . . . . . . . . . . . . . . 562

Field Experiments on the Control of the Melon Fly, Dacus cucurbitae

Previous Investigations and Practices . . . . . . . . . 563

Materials and Methods . . . . . . . . . . . . . 564

Treatment of Crop Plants . . . . . . . . . . . . . 566

Treatment of Corn Borders . . . . . . . . . . . 569

Treatment of Corn Border and Surrounding Wild Vegetation . 581

Laboratory Cage Tests of Residues Weathering in the Field . . 583

Conclusions . . . . . . . . . . . . . . . . . 588

Summary . . . . . . . . . . . . . . . . . 589

Acknowledgments . . . . . . . . . . . . . . . 591

Literature Cited . . . . . . . . . . . . . . . . 592

For abstracts of these two papers, see inside front cover 